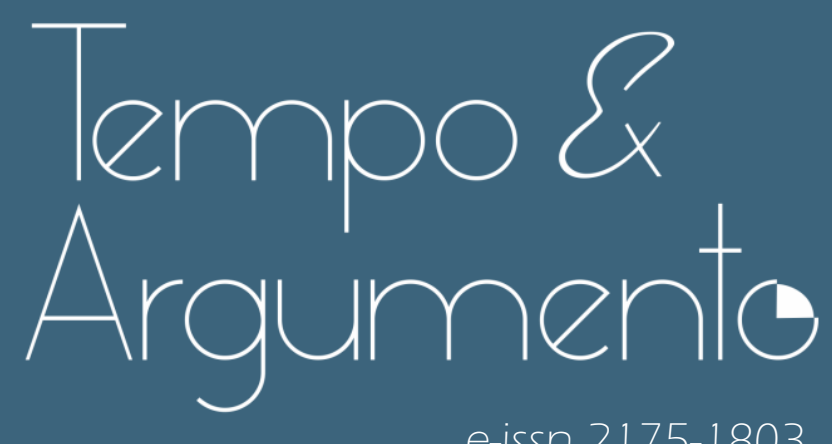

e-issn 2175-1803

Resistência, revolução e democracia: o debate sobre a luta armada na esquerda brasileira (1969-1985)

- Jean Rodrigues Sales

Doutor em História Contemporânea pela Universidade da Borgonha (UB, França).

Professor do Programa de Pós-Graduação em História da Universidade Federal Rural do Rio de Janeiro (UFRRJ).

Nova Iguacu, RJ - BRASIL

lattes.cnpq.br/8512458651817366

jeanrodrigues5@yahoo.com.br

(D) orcid.org/0000-0003-1 178-2039

Para citar este artigo:

SALES, Jean Rodrigues. Resistência, revolução e democracia: o debate sobre a Iuta armada na esquerda brasileira (1969-1 985). Tempo e Argumento,

Florianópolis, v. 12, n. 31, e0206, set./dez. 2020.

doi http://dx.doi.org/10.5965/2175180312312020e0206

Recebido: 08/08/2018

Aprovado: 24/07/2019 


\title{
Resistência, revolução e democracia: o debate sobre a luta armada na esquerda brasileira (1969-1985)1
}

\begin{abstract}
Resumo
Este artigo tem como objetivo investigar os debates realizados pela esquerda brasileira a respeito da experiência da luta armada contra o regime militar instaurado em 1964. Consideramos a inserção dessa discussão desde o momento da derrota da luta armada até a consolidação do projeto de criação do Partido dos Trabalhadores (PT), em meados dos anos 1980. A conclusão geral do texto é que a esquerda armada realizou intensa discussão sobre o significado dessa experiência até a superação crítica da proposta de luta guerrilheira e a inserção no movimento mais amplo de luta pela redemocratização no país.
\end{abstract}

Palavras-chave: Esquerda armada. Ditadura Militar. História. Memória.

\section{Resistance, revolution and democracy: the debate on armed struggle in the Brazilian left (1969-1985)}

\begin{abstract}
This article aims to investigate the debates organized by the Brazilian left on the experience of armed struggle against the military regime established in 1964. The scope of that discussion ranges from the defeat of the armed struggle to the consolidation of the project aimed at creating the Partido dos Trabalhadores (PT) [Brazil's Worker Party] in the mid-1980s. The article concludes that the armed left held an intense discussion, both in Brazil and in exile, about the meaning of this experience, including the critical overcoming of the guerrilla struggle proposal and the insertion into movements for Brazil's re-democratization.
\end{abstract}

Keywords: Armed left. Military dictatorship. History. Memory.

\footnotetext{
Este artigo é fruto de uma pesquisa de pós-doutorado realizada na Universidade de São Paulo, entre 2016 e 2017, com a supervisão do Prof. Dr. Marcos Napolitano, a quem agradeço pela possibilidade proporcionada de pesquisa na USP. Os resultados do artigo, evidentemente, são de minha responsabilidade.
} 


\section{Apresentação}

Em 1979, com o início da abertura política, centenas de militantes que estavam exilados retornaram ao Brasil. Uma parte desse grupo participou da chamada "luta armada" contra a Ditadura Militar e, na nova conjuntura política, passou a atuar nos mais diversos movimentos políticos e sociais, tais como partidos, particularmente no Movimento Democrático Brasileiro (MDB), no Partido Democrático Trabalhista (PDT) e no Partido dos Trabalhadores (PT) (FREIRE, 2014), bem como em organizações que surgiram enfatizando os problemas da ecologia, do feminismo e do combate ao racismo.

Até o momento, não há estudos sistematizados sobre o processo de modificação das bandeiras e a atuação política da parte da esquerda brasileira que, envolvida com o movimento mais amplo de redemocratização da sociedade, deixou para trás um projeto revolucionário e de luta armada contra o regime ditatorial. Ainda merecem maior aprofundamento analítico temas como a autocrítica feita pelos diversos grupos sobre a luta armada, os espaços sociais, temporais e institucionais em que essa discussão fora realizada, as divergências e propostas variadas para a atuação na nova conjuntura política.

O que encontramos na bibliografia são, em geral, aproximações que partem de pesquisas sobre vários aspectos da história da esquerda revolucionária, sem priorizar ou aprofundar um exame das mudanças pelas quais passaram as esquerdas na segunda metade dos anos 1970 e início da década de 1980. Entre outras áreas de pesquisa, são os casos particularmente importantes dos trabalhos sobre a esquerda armada e a respeito do exílio. Esses estudos estão diretamente relacionados com a geração de militantes que participou da experiência da luta guerrilheira e que, em grande parte, foi exilada ou presa, retornando ao país ou saindo da prisão ao final do regime ditatorial e engajandose em diversos projetos políticos e sociais. No entanto, enquanto a produção sobre a luta armada se preocupou com a compreensão do surgimento, prática e derrota do projeto guerrilheiro, o segundo conjunto procurou reconstituir a vivência dos militantes no exílio. Assim, não fazem parte dos horizontes de ambas as persperctivas de estudo as discussões sobre de que forma os militantes abandonaram um projeto político que tinha como cerne as ideias de 
revolução e resistência, adotando novas práticas políticas centradas nas lutas democráticas e sociais².

Caberia ainda lembrar, mesmo que brevemente, as pesquisas que se debruçaram sobre os diversos grupos de oposição que passaram atuar a partir de 1977, como o Movimento Estudantil, o Movimento Feminino pela Anistia (MFPA), os Comitês Brasileiros pela Anistia (CBAs), além dos já mencionados Movimento Negro, Movimento Feminista, etc. No caso desses estudos, não se encontra a análise da mudança ocorrida no pensamento das esquerdas, uma vez que tratam de períodos em que os grupos de esquerda já haviam abandonado a luta armada (ARAÚJO, 2000; 2007).

Uma tentativa importante de explicação das mudanças sofridas pelos projetos das esquerdas no período de redemocratização se deu em 2004, durante os debates realizados por ocasião dos 40 anos do golpe civil-militar de 1964. A discussão girou em torno do significado das ações armadas empreendidas pelos grupos revolucionários nos anos 1960 e 1970. Partindo das interpretações de Daniel Aarão Reis (2000; 2014), alguns pesquisadores defenderam que tais ações eram essencialmente ofensivas, na medida em que os grupos revolucionários não propunham a volta ao regime democrático e sim a implantação de um regime socialista. Já na perspectiva de Marcelo Ridenti (2004), as ações guerrilheiras eram, na verdade, de resistência ao regime ditatorial, ainda que nos programas e propostas dos grupos aparecessem os fins revolucionários.

De acordo com Daniel Aarão Reis (2000), e esse é o argumento que interessa diretamente a este artigo, a partir dos anos 1970, quando se encontravam no exílio, os militantes construíram uma memória que os apresentava como o polo mais radical de defesa da democracia. Com essa perspectiva política, tiveram presença importante nos movimentos de anistia,

\footnotetext{
${ }^{2}$ As duas áreas em questão contêm uma enorme quantidade de trabalhos publicados. No caso da problemática da luta armada contra a Ditadura Militar, remeto a um texto meu em que realizei um balanço da historiografia sobre o tema (SALES, 2015b). Remeto, ainda, a uma coletânea sobre diversas das organizações guerrilheiras (SALES, 2015a). No caso das pesquisas sobre o exílio das esquerdas, ver Rollemberg (1999); Marques (2011); Cruz (2010; 2016), Napolitano (2014) e Chirio (2004).
} 
inicialmente quando se encontravam fora do país e, a partir de 1979, quando retornaram ao Brasil. Além disso, segundo Aarão Reis (2014), os militantes teriam afirmado que a luta armada se dera como resposta ao fechamento do regime com o Al-5, quando, na verdade, sua ideia antecedia 1964 e sua implementação se teria dado antes de 1968. Para o autor, essa imprecisão constituiria mais uma operação de construção de uma memória apaziguadora. Haveria acontecido uma metamorfose de guerrilheiros em democratas, ocultando assim os aspectos da proposta ofensiva do projeto socialista. Essa mudança atenderia também aos interesses de setores da sociedade que preferiam que não viessem à tona temas dos sombrios anos ditatoriais, o que permitia à esquerda armada compor o amplo movimento de oposição democrática da sociedade brasileira contra o regime militar. Um exemplo apontado por Aarão Reis (2014, p. 133) que demostraria o "deslocamento de sentido" das ações guerrilheiras foi a ampla aceitação por parte da sociedade, em 1979, da versão apresentada por Fernando Gabeira, em seu livro o que é isso companheiro? ${ }^{3}$, que apresenta a luta armada como uma ação de jovens idealistas e opositores do regime ditatorial.

Outros autores, como Denise Rollemberg, também fazem uso da proposta analítica de Aarão Reis, enfatizando que as esquerdas quiseram esquecer elementos marcantes da luta armada, como o seu próprio isolamento social, a violência, as mortes, etc. Nesse caminho, elas também contribuem para o esquecimento, para um "lembrar que esquece", na medida em que não transparecem os aspectos ofensivos acima mencionados (ROLLEMBERG, 2006, p. 90). Ainda um terceiro autor, em percurso argumentativo próximo aos dos dois anteriores, afirmou, sem demonstrar qualquer evidência, que essa memória construída pela esquerda a partir da redemocratização não deixava transparecer "a ideia de que a interrupção da democracia em 1964 teria incentivado a deflagração da luta armada não encontra a base na realidade", uma vez que o engajamento armado, "[...] visando à tomada do poder era visto como uma

\footnotetext{
${ }^{3}$ Em 1997, o cineasta Bruno Barreto levou às telas o filme baseado no livro de Fernando Gabeira. A narrativa e representação crítica em relação aos militantes das organizações guerrilheiras, ao mesmo tempo em que relativizava o papel dos torturadores, causou uma grande discussão nos meios intelectuais brasileiros. Parte da discussão pode ser vista em Aarão Reis (1997).
} 
estratégia política antes mesmo do golpe contra João Goulart” (ANGELO, 2011, p. 190, grifo nosso) 4 .

Creio que falta na proposta analítica de Reis (2000, 2014), bem como nas trabalhos de Rollemberg (2006) e Angelo (2011), o que Carlos Fico identificou como a explicação sobre "a persistência desse deslocamento de sentido ao longo das diversas conjunturas que vão da época da Lei da Anistia de 1979 até o momento em que a Comissão da Anistia, em 2002, foi criada [...]." (FICO, 2017, p. 37). Em outras palavras, caberia apontar as modificações e percurso na construção dessa memória apaziguadora da esquerda sobre a luta armada desde o final da experiência guerrilheira. Nesse sentido, continuam merecendo aprofundamento analítico e empírico as fontes que podem nos informar sobre a metamorfose dessa memória, quais militantes, organizações ou veículos debateram a questão da luta armada no período e em quais conjunturas políticas as ideias de esquecimento da violência e adesão a um programa democrático ganhou espaço entre os militantes. Seria necessário, utilizando os termos próprios às discussões sobre memória, acompanhar os vetores sociais da memória (POLLAK, 1989; 1992) das esquerdas armadas no decorrer dos anos 1970 e 1980 para que possamos compreender o abandono de uma identidade guerrilheira e revolucionária, e a consolidação de um sentimento de pertencimento a um novo projeto político, cujo centro são a democracia e os direitos sociais e individuais (POLLACK, 1989, 1992; SILVA, 2002).

De meu ponto de vista, para se compreenderem as mudanças das esquerdas e seus militantes entre final dos anos 1970 e início dos anos 1980, particularmente no que diz respeito à luta armada e à democracia, faz-se necessário acompanhar como essa discussão transcorreu no seio da esquerda no período em questão até que se tenha conformado uma memória hegemônica ${ }^{5}$ sobre a luta guerrilheira no Brasil.

\footnotetext{
${ }^{4}$ Ainda sobre a perspectiva que aponta a existência de um projeto de luta armada por parte das esquerdas antes de 1964, ver Rollemberg (2003).

${ }^{5}$ O historiador Marcos Napolitano (2015) propõe que chegou a se formar no Brasil uma "memória hegemônica" crítica ao regime militar. Essa memória seria formada pela junção de setores liberais e das esquerdas (sobretudo do PCB). No caso da proposta deste artigo, faço a discussão sobre a memória específica da esquerda, e não da ditadura militar de forma geral.
} 
Ao fazer um percurso histórico dos debates sobre a luta armada, e da construção social dessa memória, evitamos o equívoco que a historiadora francesa Maud Chirio (2004) identificou em muitos estudos sobre a história das esquerdas brasileiras entre os anos 1960 e 1980: o período de permanência da militância no exílio é compreendido como uma espécie de hiato na vida desses militantes. Ou seja, o fenômeno é visto como se houvesse uma atuação antes do golpe civil-militar e um retorno cerca de dez anos depois, a partir do qual os participantes seriam naturalmente reinseridos na política nacional. O período vivido no Chile, na França, na Argélia, em Portugal e em outros países não passaria de um longo tempo em que se aguardava o retorno ao Brasil. Ainda de acordo com a autora francesa, as experiências, debates e transformações sofridas pelas esquerdas e seus militantes no exílio (eu acrescentaria, também na prisão) transformaram as suas ideias e as suas práticas políticas. Dessa forma, devemos entender tal período como parte da trajetória política dessa geração, e não como um capítulo separado de suas trajetórias pessoais. Sem essa perspectiva, não se torna inteligível como os novos projetos políticos, que seriam vivenciados nos anos 1980, foram debatidos e elaborados no decorrer dos anos 1970.

Este artigo pretende contribuir para a compreensão do processo de crítica e afastamento da esquerda brasileira da proposta de revolução e do uso da luta armada como ação política. Parto da premissa de que esse debate ocorreu em diversos espaços temporais e institucionais, alem de ter sido realizado coletiva e individualmente. Entre outras formas possíveis para a compreensão desse fenômeno, vale destacar as discussões ocorridas no exílio, na prisão, na chamada imprensa alternativa e entre militantes que permaneceram no Brasil, atuando nas fábricas, nos sindicatos e no que se convencionou chamar de "novos movimentos sociais", surgidos a partir de meados dos anos 1970.

O texto não pretende dar conta de todas as dimensões envolvidas no processo de crítica da luta armada. O meu propósito é circunscrever a discussão em torno de cinco grandes temas. Começo por uma breve introdução ao debate sobre a problemática da luta armada entre os grupos de esquerda no momento de fragmentação do Partido Comunista Brasileiro (PCB) e do surgimento e desenvolvimento das ações armadas. Em seguida, acompanho o debate no exílio, 
inicialmente no Chile e, posteriormente, na França. O terceiro elemento analisado consiste nas discussões feitas por militantes e organizações que continuavam atuando de forma dispersa e clandestina no Brasil. Em seguida, discuto o tema a partir da chamada "imprensa alternativa", já no período da distensão política. Por fim, trato dos debates entre algumas organizações e militantes no momento da criação do Partido dos Trabalhadores, que significaria, para muitos, um exemplo prático da superação do projeto de luta guerrilheira.

\section{As esquerdas e o princípio do debate}

Discussões sobre a estratégia da luta armada ou do uso da violência revolucionária podem ser vistas nas esquerdas brasileiras desde antes do golpe civil-militar de 1964. Na ocasião, organizações como o Partido Comunista do Brasil (PCdoB), a Ação Popular (AP) e a Organização Marxista Leninista - Política Operária (Polop) criticaram a postura pacifista do Partido Comunista Brasileiro (PCB) propondo certa radicalização de ações revolucionárias, além de apontar para a perspectiva de uma revolução socialista, sem necessariamente reivindicar o uso da luta armada. Esse debate, anterior ao golpe, se deu sob forte influência da Revolução Cubana. De fato, o caminho seguido por Cuba em 1959 foi apontado, ao mesmo tempo, como exemplo crítico à política pacifista praticada pelos partidos comunistas no continente e como inspiração para as esquerdas das Américas (SALES, 2007). No caso do Brasil, porém, antes do golpe de 1964, o exemplo cubano não levou as organizações ao uso das armas, com a exceção de um episódio envolvendo um grupo minoritário de militantes das Ligas Camponesas ${ }^{6}$.

\footnotetext{
${ }^{6}$ Alguns autores têm apontado o caso do chamado campo de treinamento guerrilheiro das Ligas Camponesas, em 1963, como comprovação da existência de um projeto de ofensiva revolucionária, com uso de armas, antes golpe de 1964 (ANGELO, 2011; ROLLEMBERG, 2003). De meu ponto de vista, essa perspectiva não se sustenta por uma série de motivos. O primeiro, e mais importante, é que me parece desproporcional transpor para o conjunto da esquerda pré1964 o caso de um grupo minoritário das Ligas Camponesas. Em segundo lugar, e em consonância com o primeiro exemplo, ao analisarmos os projetos políticos dos principais grupos das esquerdas brasileiras no período anterior ao golpe (são os casos, por exemplo, do PCB, PCdoB, AP, Polop), não encontramos perspectivas de uso da luta armada a curto ou médio prazo. Quadro esse que se modificaria claramente após o golpe civil-militar de 1964, quando essa esquerda, em sua maior parte, aderiu ao uso das armas. Cf. Sales (2007).
} 
Foi a partir da crise aberta pela vitória do golpe em 1964 que a maior parte das esquerdas adotou, não sem passar por debates e cisões, o uso das armas como forma de luta contra o regime militar. Parte significativa dos grupos que participou da luta guerrilheira surgiu a partir de cisões no PCB, até aquele momento maior agremiação da esquerda brasileira. O processo de cisão partidária se consolidou após a realização de seu VI Congresso, em 1967, durante o qual estavam em pauta as táticas e estratégias de luta contra o regime militar. No entanto, o restante da esquerda de inspiração socialista ou comunista também não ficaria imune ao debate sobre a luta armada. Nesse caminho, no decorrer da segunda metade dos anos 1960, PCdoB, Polop e Ação Popular (AP) também sofreram cisões relacionadas às discussões sobre o enfrentamento da ditadura militar e a adesão à luta armada?

Para os objetivos deste artigo, porém, interessa-me destacar a discussão no momento em que as diversas organizações da esquerda armada já se haviam constituído. A esse respeito, vale salientar, o debate no seio da esquerda revolucionária acerca da viabilidade da luta armada esteve presente desde o início das ações guerrilheiras. A questão aparece, por exemplo, nas constantes discussões entre as chamadas alas "massista" e "militarista" das organizações. A primeira perspectiva entendia que era necessário, mesmo com as ações armadas, ter um trabalho de base social, buscando atuar nos sindicatos, associações de bairro, entre outros locais. Partia-se do entendimento de que as ações armadas, isoladas da sociedade, não seriam suficientes para derrubar a ditadura militar ${ }^{8}$.

A ala "militarista", como a própria designação sugere, defendia a necessidade da luta armada como método praticamente exclusivo de ação. Essa postura, por sua vez, vinculava-se a uma áspera crítica à atuação do PCB no período anterior ao golpe civil-militar de 1964 e à defesa da ideia de que não era possível atuar contra o regime senão a partir das armas, através de uma releitura

\footnotetext{
Não faz parte dos objetivos deste artigo realizar uma reconstituição do processo de fragmentação da esquerda brasileira após o golpe de 1964. Sobre o tema, ver: Reis Filho (1990); Gorender (1987); Ridenti (1993) e Sales (2007). Para uma apresentação da bibliografia existente sobre a experiência de luta armada da esquerda abrasileira nos anos 1960 e 1970, ver Sales (2015). ${ }^{8}$ Os principais trabalhos sobre a história da luta armada no Brasil tratam das discussões entre "massismo" e "militarismo". Ver, entre outros, os já citados Ridenti (1993); Gorender (1987); Reis Filho (1990) e Sales (2007, 2015).
} 
do foquismo9. Nessa perspectiva de luta, ganhou destaque o lema da Ação Libertadora Nacional (ALN), de Carlos Marighella, ao propugnar que somente a ação faz a revolução.

Trazer para cá o debate sobre "massismo" e "militarismo" não significa negar a predominância do caminho armado entre as esquerdas no período, mas serve para chamar a atenção para que, ainda durante as ações guerrilheiras, havia um espaço de crítica e debate em torno do uso exclusivo do caminho armado. Dessa forma, é possível compreender como, no momento de autocrítca da luta armada, alguns desses debates tenham sido retomados no exterior e em outros espaços.

Uma das primeiras organizações a discutir claramente os limites da luta armada foi o Partido Comunista do Brasil - Ala Vermelha (PCdoB-AV). O grupo surgiu em 1967, em decorrência de uma cisão no PCdoB, motivada principalmente pela participação efetiva nas ações guerrilheiras. Ao se estruturar, a Ala Vermelha acusou o partido de não agir militarmente contra a ditadura, enquanto outros grupos estavam em plena ação armada contra o regime militar (RIBEIRO, 2013; SILVA, 2007).

Como consequência das ideias defendidas em sua origem, a Ala se inseriu imediatamente nas ações armadas. Dois anos depois, porém, começou a reavaliar a conjuntura nacional e a opção que fizera pelo caminho das armas. 0 documento que marcou o início do processo de autocrítica da organização ficou conhecido como "Os 16 pontos", sendo aprovado em uma reunião realizada em novembro de 1969, no estado do Rio de Janeiro. O texto criticava o foquismo, que tomara conta das organizações de esquerda, e apontava a necessidade de aproximação do operariado industrial, com o objetivo de fortalecer as lutas para a derrubada da ditadura e a implantação de um governo popular revolucionário:

\footnotetext{
9 O termo "foquismo" é empregado aqui de forma ampla, como era utilizado entre as esquerdas nos anos 1960 e 1970, caracterizando movimentos que, influenciados pela Revolução Cubana, consideravam ser possível fazer uma revolução socialista através da guerra de guerrilhas e sem a presença de um partido comunista como dirigente do movimento insurrecional. Acreditavase que esse era o caminho adequado para a América Latina e que as condições objetivas estavam prontas, restando criar as condições subjetivas, tarefa essa a que a presença do foco guerrilheiro se encarregaria. Uma vez iniciados os combates, as massas acabariam por se aliar aos guerrilheiros e estes conseguiriam aumentar o seu poder ofensivo até a vitória da revolução. Durante o processo revolucionário, a guerrilha seria a vanguarda política, estando todas as outras tarefas a ela subordinadas (SALES, 2007).
} 
O trabalho no seio da classe operária e das massas revolucionárias visa à Educação, a preparação e a organização das massas para a luta política e para a luta armada. Por isso é necessário incentivar ao máximo as lutas de classe operária, tomando como ponto de partida a luta econômica, elevando-a ao nível político, indicando o caminho da luta armada e organizando-a para esta luta [...]. Nesse incentivo deve-se incrementar a luta operária contra o arrocho salarial, contra o Fundo de Garantia, contra a lei antigreve, contra a intervenção nos sindicatos, contra o regime policialesco e de repressão a que são submetidos os operários. Tais lutas devem ser desencadeadas objetivando transformá-las em luta pela derrubada da ditadura e instauração de governo popular sob sua hegemonia. (ALA VERMELHA, 1969, p. 4-6)

Vale destacar que o documento apontava a necessidade de incentivar a classe operária a tomar o caminho da luta armada e, simultaneamente, apresentava uma série de objetivos táticos bastante próximos da plataforma que marcaria as ações das esquerdas em meados dos anos 1970, particularmente no que diz respeito à centralidade de atuação entre os trabalhadores fabris.

Com a derrota da esquerda armada no início dos anos 1970, em um documento intitulado "Autocrítica", aprovado em 1974, a Ala Vermelha intensificou suas discussões em torno das ações armadas e do seu isolamento social. Na nova conjuntura política, o objetivo principal era agir junto aos movimentos sociais e, a partir dessa atuação concreta, criar as condições necessárias à fundação de um partido político de vanguarda. Para isso, a organização deveria

[...] localizar as lideranças naturais e com elas efetuar um trabalho de capacitação política e ideológica e incentivar as formas de organização que possam servir para a união dos operários a partir das fábricas. No curso desse processo e na medida em que os marxistas-leninistas se fundam à luta de classes concreta, colocase a tarefa de construir o partido de vanguarda do proletariado garantia de que todo o movimento se orientará no sentido do cumprimento do papel histórico da classe operária. (ALA VERMELHA, 1974, p. 84-85)

Outras organizações também debateram a problemática do "massismo" e do "militarismo" ainda no final da década de 1960, em pleno desenrolar das ações armadas. É o caso da Vanguarda Popular Revolucionária (VPR), organização que surgiu em 1968 a partir da junção de dissidentes da Polop e do Movimento Nacionalista Revolucionário (MNR), ligado ao nome de Leonel Brizola e 
responsável pela experiência da chamada "guerrilha do Caparaó". A VPR ficaria conhecida pelo ingresso em suas fileiras do capitão do Exército Carlos Lamarca, que deixou as forças armadas com um carregamento de fuzis, tornando-se, por essa razão, um dos militantes mais procurados no país (CHAGAS, 2000; SALES, 2015a).

Em 1969, um ano após o surgimento da VPR, apareceram internamente duas tendências sobre as possibilidades de atuação. De um lado, o setor "urbano", formado por trabalhadores, estudantes e intelectuais; e, de outro, o setor "logístico", composto principalmente por militares cassados pelo regime ditatorial. Enquanto o primeiro grupo propunha uma maior inserção junto às bases sociais e a diminuição das ações armadas, o segundo setor defendia as ações armadas como fundamento de uma organização revolucionária atuando sob um regime ditatorial.

Em meio aos debates internos entre as duas correntes, a decisão sobre a saída ou a permanência de Carlos Lamarca no Exército acabaria se tornando o ponto de divisão da organização. O setor urbano defendia que a Lamarca seria mais útil permanecer nas forças armadas e buscar atrair novos militantes em suas fileiras. Além disso, argumentava que a VPR não possuía condições de arcar com as consequências da deserção de um militar com um carregamento de armas. O setor logístico, em contrapartida, avaliava que aquela seria uma oportunidade única de conseguir mais armas e desmoralizar o Exército.

Para a resolução do impasse, foi realizada uma reunião no final de 1968, na qual prevaleceu a proposta do setor urbano. A despeito disso, o grupo que defendia as ações armadas não obedeceu à orientação, continuando com as atividades militares e, ainda, expulsou, no início de 1969, alguns membros do setor crítico ao militarismo. Após esse episódio, o militante Ladislau Dowbor, conhecido como Jamil, escreveu o documento intitulado "A vanguarda armada e as massas na primeira fase da revolução", que se tornou o texto mais representativo da defesa do papel central das ações armadas, em detrimento da atuação das massas. Por sua vez, o principal representante do setor urbano, o professor João Quartim de Moraes, após sua expulsão, exilou-se em Paris e organizou a revista Debate: Problemas da Revolução Brasileira, a qual, conforme 
veremos adiante, se tornaria um veículo importante na crítica ao militarismo das entidades de esquerda brasileiras.

Há outros exemplos de debates nas organizações da esquerda revolucionária em torno da viabilidade da luta armada, que apareceram nos termos "massismo" versus "militarismo". Porém, creio que os casos da Ala Vermelha, pelo pioneirismo, e o da VPR, por ter resultado em uma cisão ainda em 1969, sejam os mais representativos dessa contenda enquanto ainda se desenvolviam as ações armadas contra a ditadura. As outras organizações, militantes e ex-militantes, de forma geral, fizeram a crítica da luta armada no exílio, particularmente no Chile e na França.

É importante lembrar que o processo de autocrítica da esquerda em relação à luta armada não seguiu uma trajetória linear e, tampouco, foi compartilhado pelo conjunto de militantes que se encontravam em luta no Brasil. Além disso, as organizações que ainda persistiam na guerrilha acabaram sofrendo novas cisões nesses momentos finais de existência da esquerda revolucionária, o que colocava maiores problemas para a compreensão da situação do país e da prática política. Assim, por exemplo, ao mesmo tempo em que setores da Ala Vermelha e da VPR faziam críticas ao caminho armado, o jornal Resistência, publicado no Brasil pela ALN e pelo Movimento Revolucionário 8 de Outubro (MR-8), continuava fazendo a defesa da luta armada. Em uma edição de novembro de 1972, voltada para o Chile e escrita em espanhol, o periódico anunciava que

Apesar da intensa repressão no Brasil (em consequência do sequestro do embaixador suíço), as ações revolucionárias se desenvolvem normalmente. Nos últimos três meses foram realizadas diversas ações de propaganda armada. Entre elas, destacamos a tomada do posto policial da favela de Jacarezinho, onde houve distribuição de panfletos; a expropriação do Banco Nacional de Minas Gerais; expropriação da fábrica da coca-cola; expropriação da Loteria Esportiva; assalto ao banco Andrade Arnaud, na Tijuca; assalto ao carro de transporte de valores da empresa imperialista Moinho da Luz; distribuição de 10.000 mil panfletos esclarecendo ao povo sobre os motivos do sequestro do diplomata suíço (rompendo a censura à imprensa); ações de tomada de armas e uniformes policiais. Todas estas ações se realizaram no Rio de Janeiro, fazendo ver à repressão e ao povo que os revolucionários são incansáveis em sua luta. (ALN, MR-8, 1972, p. 3) 
Outro exemplo representativo da defesa da luta armada por parte de setores da militância no momento de claro descenso de sua capacidade de enfrentamento é o caso do Movimento de Libertação Popular (Molipo), grupo que surgiu de uma cisão da ALN. Os militantes que formaram o agrupamento, cuja maior parte se encontrava em treinamento em Cuba, retornaram ao Brasil em 1971 com o objetivo de intensificar as ações armadas, quando as organizações guerrilheiras, na prática, já haviam sido derrotadas (ROLLEMBERG, 2001; GORENDER, 1998; DIRCEU, 2018).

Como podemos observar, discussões entre as esquerdas sobre a luta armada se iniciaram ainda enquanto as organizações atuavam contra o regime militar. Abordamos acima dois casos, da Ala Vermelha e da VPR, mas poderíamos ampliar para outros grupos. De todo modo, como defendemos neste artigo, a parte substancial do processo de autocrítica da esquerda em relação à luta armada ocorreu no exílio.

\section{No exílio, em debate}

O aparato policial da Ditadura Militar prendeu, matou e baniu do país centenas de militantes das organizações de esquerda, particularmente após o Ato Institucional número 5 (Al-5). De forma geral, o exílio marcou o momento mais importante de reavaliação da luta armada. Ainda que, em seus primeiros anos, particularmente no Chile e em Cuba, uma parte dos militantes exilados se preparasse para retornar ao Brasil clandestinamente para continuar as ações armadas, aos poucos se colocou a discussão sobre possíveis erros e insuficiências dessa tática ${ }^{10}$.

O processo de autocrítica se intensificou quando aconteceu o golpe que derrubou o governo de Salvador Allende, em 1973, e os militantes foram para a Europa. O golpe no Chile, além das questões práticas envolvidas, como a imposição de mais uma mudança de país, também teve um grande significado simbólico para os militantes que viam uma proposta de socialismo ser derrubada

\footnotetext{
10 Para uma discussão sobre o exílio de militantes brasileiros, ver: Rollemberg (1999); Marques (2011); Cruz (2010; 2016), Napolitano (2014) e Chirio (2004).
} 
pelos militares chilenos. A revolução, para essa geração de militantes que já havia sido derrotada no Brasil, parecia então ainda mais distante.

Uma vez instalados no velho continente, em contato com novas ideias no campo das esquerdas, os militantes conheceram as transformações mais importantes dos setores revolucionários no sentido do abandono da ideia de luta armada e da adoção de uma perspectiva de atuação junto às bases da sociedade. Além disso, novos horizontes, como o feminismo, o movimento ecológico, o movimento negro, a luta por direitos trabalhistas e sociais, aos poucos dividiam a atenção da militância com a problemática da revolução (CHIRIO, 2004).

O processo de autocrítica no exílio foi complexo e diversificado, uma vez que foi realizado por pessoas que deixaram a militância organizada, por agrupamentos que mantiveram a estrutura organizativa, bem como por diversas cisões que ocorreram no exterior. Além disso, foram ainda formados coletivos de discussões em torno de projetos editoriais e grupos de debate político que agregavam diversas correntes de pensamento. Diante dessa variedade das posições das esquerdas, para acompanhar a trajetória da autocrítica no exterior, utilizo as publicações de periódicos ${ }^{11}$ que representam as posições de uma ou mais organizações. Cabe ainda salientar que os brasileiros se exilaram em muitos países, porém, para a discussão deste artigo, vou destacar os casos do Chile e da França.

Uma das revistas pioneiras no exílio chileno foi a Temas y Debates, editada por ex-militantes de várias organizações, tendo como propósito servir de espaço de discussão e de aglutinação da esquerda revolucionária. O periódico inicialmente foi escrito em português e, em seguida, em espanhol, para atingir um público maior nas condições do exílio chileno.

No primeiro número da revista, publicado em setembro de 1970, o artigo intitulado "Alguns problemas da luta armada no Brasil" apontou diversas dificuldades enfrentadas pela esquerda revolucionária. Entre outros pontos, o

Durante o exílio dos militantes, foram publicadas dezenas de periódicos de várias características. Além dos jornais das diversas tendências políticas, havia aqueles voltados para a denúncia das prisões e torturas e outros que se propunham a divulgar notícias sobre o Brasil para os exilados. Pelos objetivos e pelo tema desta pesquisa, utilizarei aqueles periódicos mais claramente ligados às organizações e militantes de esquerda. 
texto afirma que faltavam às organizações uma estratégia clara de longo prazo e uma definição quanto ao caráter da luta revolucionária (ALGUNS..., 1970). Além disso, os grupos padeciam da clara atomização, distanciando-se enormemente das lutas dos trabalhadores e dos sindicatos. Somavam-se aos problemas políticos as dificuldades na estrutura organizacional, fortemente atingida pela repressão política (ALGUNS..., 1970).

É importante ressaltar que, mesmo não afirmando que as ações armadas estivessem derrotadas pelo regime militar, o artigo, ao elencar as dificuldades enfrentadas pelas esquerdas, deixa subentendido que estas dificilmente conseguiriam superar seus problemas nas condições ditatoriais. Ademais, o texto mostra-se importante por apresentar no exterior a problemática do isolamento social das esquerdas, tema que já havia surgido em parte dos grupos no Brasil. conforme veremos adiante, essas críticas embrionárias cresceriam nos anos seguintes entre os militantes no exílio.

Em 1971, a revista Temas y Debates publicou o documento "Uma autocrítica necessária", assinado pela Tendência Leninista da Ação Libertadora Nacional (TL), grupo que surgiu no exterior após os duros golpes sofridos pela ALN, que praticamente deixou de existir após a morte de Joaquim Câmara Ferreira. Nesse momento, alguns militantes voltaram para o Brasil, enquanto outros permaneceram no exterior. O documento em questão é um elemento importante na autocrítica feita pela esquerda revolucionária brasileira no exterior. Ainda que seja próximo do que outros grupos elaborariam no mesmo período, seu conteúdo foi fruto da reflexão de militantes que faziam parte da organização que era um dos símbolos da luta armada, o que era em grande parte alimentado pela simbologia de seu principal líder, Carlos Marighella (TL, 1975).

O documento faz uma profunda crítica ao foco guerrilheiro e ao militarismo que teria tomado conta das organizações, ao afirmar que essa teoria seria a negação do partido leninista. Para a TL, era necessário voltar-se para o trabalho junto às classes trabalhadoras e para a criação de um partido revolucionário. Por fim, cabe destacar que se trata de um texto pioneiro ao aceitar que, em certas 
condições, seria necessário usar as eleições como meio político tático de luta contra o regime militar ${ }^{12}$.

Em 1973, a revista aprofundou a indicação de inserção da militância junto às classes trabalhadoras, para com isso romper o isolamento social da esquerda revolucionária. Nesse momento, aparece uma proposta de atuação junto ao processo de lutas institucionais contra a ditadura militar que se instaurava lentamente no país. Vale ressaltar que a ambiguidade sobre a participação na Frente Democrática em formação foi tema relevante de discussão das esquerdas na segunda metade dos anos 1970, uma vez que implicava refletir acerca das características reformistas ou revolucionárias das esquerdas. Em outras palavras, colocava-se em questão a participação dos grupos de esquerda em um movimento claramente hegemonizado pela "oposição burguesa". Como resposta, o editorial da revista apontava que

Na luta pela institucionalização que se abre dentro do bloco dominante, e que a oposição burguesa apresenta como luta pela "abertura democrática", a esquerda deve levantar suas bandeiras. A luta pelas liberdades democráticas assinala um sentido comum, implícito nas movimentações embrionárias das massas ao mesmo tempo que assinala um caráter político que elas ainda não assumiram claramente. Ao mesmo tempo que impulsiona as lutas elementares que se gestam atualmente, a esquerda revolucionária deve levantar os objetivos democráticos locais, as liberdades sindicais, de expressão, de reunião, etc. Deve também em sua propaganda levantar de modo mais consequente uma plataforma de luta por liberdades políticas que em cada momento e oportunidade deve ser agitada para que ganhe as massas, e assinalar uma perspectiva comum que unifique as lutas e transfira a bandeira democrática das mãos hesitantes da oposição liberal para as mãos seguras da esquerda revolucionária. (EDITORIAL, 1973, p. 5, tradução nossa)

A Tendência Leninista, juntamente com outros militantes, criaria ainda o seu próprio jornal, o Unidade e Luta. Pela Reunificação dos Marxistas Leninistas Brasileiros, no qual apresentaria, de forma mais aprofundada, seus posicionamentos a respeito da situação das esquerdas e do Brasil. Assim como

\footnotetext{
12 No número seguinte da revista, a TL denunciaria que a direção da ALN havia ignorado os argumentos apresentados no documento "Uma autocrítica necessária" e se negava a realizar um congresso para se discutirem as divergências internas. Cf.: TL. Comunicado de la Tendencia Leninista da ALN. Temas y Debates, Santiago, n. 6, março-abril de 1972, p. 28.
} 
outros periódicos publicados no exílio, o Unidade e Luta se colocava como instrumento de discussão e aglutinação dos revolucionários no exterior. Tinha como premissa que, para superar a atomização e dispersão que tomara conta das esquerdas, era necessário retornar ao verdadeiro marxismo-leninismo, abandonado tanto pelos revisionistas e pacifistas (caso do PCB) quanto pela esquerda militarista (TL..., 1972).

Entre os pontos defendidos pelo Unidade e Luta, chama atenção a discussão em torno das liberdades democráticas no Brasil. Enquanto alguns grupos eram intransigentes na negação dessa bandeira, os militantes da Tendência Leninista argumentavam que, no momento em que os movimentos sociais se encontravam em refluxo e as organizações revolucionárias estavam "golpeadas pela repressão" e isoladas da sociedade, as lutas democráticas poderiam ter uma dupla função. Em primeiro lugar, serviriam para reativar as lutas de massa no país, permitindo a criação de organismos que pudessem expressar seus interesses. Em segundo lugar, abririam caminho para a constituição do "partido revolucionário do proletário" (TL, 1972a, p. 29). Aos grupos de esquerda que desconfiavam de uma frente política liderada por setores liberais, afirmavam que

Conscientes das limitações e ilusões de classe dos democratas burgueses e pequeno-burgueses, não tememos, porém, alianças com eles. Ao contrário, achamos possível e desejável uma frenteúnica, em torno de um elenco de reivindicações democráticas, com todos os setores sociais dispostos a batalhar por elas.

Aos que hoje pedem o fim do Al-V, anistia política, liberdade de reunião, organização e expressão, dizemos: estamos de acordo. Mas, acrescentamos: é preciso mobilizar e organizar os trabalhadores, os estudantes, os intelectuais, etc. Para conquistálas! (TL, 1972a, p. 29)

Em 1973, o jornal publicaria um longo artigo no qual analisava a história da ditadura e das esquerdas, apontando as tarefas necessárias para a atuação política. De forma geral, seus autores seguiam muitas das ideias já expostas no documento "Uma autocrítica necessária", como a crítica ao militarismo que tomara conta das esquerdas, a necessidade de um partido revolucionário do proletariado que voltasse às fontes do leninismo, a identificação do regime como uma "ditadura fascista", a centralidade da luta pelas liberdades democráticas, 
etc. No entanto, destaco um ponto importante na temática da autocrítica da luta armada e da adoção de uma nova perspectiva que coloca a luta pelo socialismo em plano secundário em relação ao enfrentamento da ditadura. Para o grupo, nas condições em que se encontravam as lutas políticas e sociais,

[...] rejeitamos a luta pela revolução socialista imediata e reafirmamos, como fizemos no ACN, nossa luta consequente por um regime de democracia avançada que deve ser compreendido como parte de um mesmo processo da revolução permanente em direção ao socialismo. (TL, 1973, p. 12)

Outro jornal de militantes publicado no Chile foi o Campanha, periódico criado pela Fração Bolchevique, grupo que teve origem em 1970, no Rio de Janeiro, a partir de uma cisão na Organização de Combate Marxista-Leninista Política Operária (OCML-PO). O grupo, portanto, segue a tradição, de certa forma, da primeira ORM-Polop, surgida ainda antes do golpe de 1964.

Nesse sentido, vale destacar que o jornal Campanha e a Fração Bolchevique eram formados por militantes que, embora oriundos de organizações que haviam sido atraídas pelo caminho das armas, não chegaram a ser chamadas propriamente de militaristas, tendo mantido uma reflexão sobre a necessidade da presença dos trabalhadores na luta política. Assim, as ideias dessa corrente têm origens distintas de organizações como a ALN, a VPR, o MR8, a VAR-Palmares, entre outras, cujas táticas políticas foram predominantemente marcadas pela centralidade da luta armada, ainda que, em muitos casos, com espaço para discussão sobre a necessidade de atividades de massa. Dessa forma, a análise do jornal Campanha amplia seu espectro para um campo mais amplo entre as esquerdas dos anos 1960 e 1970.

No primeiro número do jornal, anunciava-se o objetivo de "fazer do exílio uma campanha" (FRAÇÃO BOLCHEVIQUE, 1972) de luta contra o regime ditatorial através da difusão de informações, denúncias, do debate e da construção de uma Frente de Esquerda. Além disso, um ponto particularmente relevante para o grupo consistia na defesa da atuação dos militantes junto aos trabalhadores, em seus locais de trabalho, buscando entender as necessidades e reivindicações básicas: 
[...] no atual momento em que não existe um partido revolucionário da classe trabalhadora, acreditamos que a construção do partido de que necessitamos passa pela realização de duas tarefas: a formação de uma vanguarda política socialista, diretamente vinculada às massas trabalhadoras em todo o país, a partir de trabalhadores de vanguarda hoje existentes; e a formação de uma Frente de Esquerda Proletária que reúna os setores dispersos da esquerda e que dê verdadeiramente à tarefa de formação da vanguarda uma amplitude nacional (FRAÇÃO BOLCHEVIQUE, 1972, p. 5, tradução nossa).

No que diz respeito propriamente à luta armada, o grupo faz duras críticas ao militarismo que teria tomado conta das esquerdas, sem negar, contudo, que o uso da violência poderia ser necessário em um processo revolucionário. A luta armada a que se refere é aquela que deveria ser realizada pelos trabalhadores da cidade e do campo e não por uma vanguarda isolada (FRAÇÃO BOLCHEVIQUE, 1972, p. 5). Compreendia-se, portanto, que a esquerda revolucionária estaria completamente desligada da sociedade, particularmente da classe operária. Além disso, os seus militantes estariam desvinculados das experiências passadas e recentes das lutas sociais, na medida em que vários deles estariam mortos, presos ou no exílio, o que agravaria ainda mais a situação de desagregação orgânica (FRAÇÃO BOLCHEVIQUE, 1972a, p. 9-10).

Vale destacar que, apesar das críticas à esquerda armada, o jornal dedicou espaço à divulgação das notícias relativas à guerrilha do Araguaia, que se processava naquele momento. Em seu primeiro número, chamava a atenção para o envio de milhares de soldados para a região de Marabá, publicando o "Comunicado do comando guerrilheiro do Araguaia". Possivelmente o grupo dedicou esse espaço ao tema porque a experiência do Araguaia se diferenciava das atividades da esquerda armada na cidade e por solidariedade e apoio aos militantes do PCdoB que estavam lutando contra os militares.

A proposta do grupo para sair da situação de isolamento em que se encontravam as esquerdas era a inserção nos movimentos sociais, principalmente no movimento operário. Coincidindo com as aspirações de outros grupos, e coerente com a tradição da ORM-Polop, o Campanha defende a centralidade da criação de um partido operário (FRAÇÃO BOLCHEVIQUE, 1972a, p. 9-10). 
Em novembro de 1974, já com sede em Paris, o jornal Campanha publicou a opinião de algumas organizações a respeito do significado e da forma de participação das esquerdas nas eleições de novembro de 1974. Possivelmente, esse documento se constitui como um dos mais relevantes no processo de autocrítica dos grupos revolucionários, pois a discussão de como as esquerdas, em meados dos anos 1970, pensavam a questão eleitoral ganharia espaço nas discussões dos anos seguintes, na medida em que se aproximava o início da abertura política no Brasil. É interessante também por revelar possíveis formas de atuação dessa esquerda no momento em que ela se afastava da luta armada (FRAÇÃO BOLCHEVIQUE, 1974, p. 7-11).

As organizações convidadas a participar da discussão foram Partido Operário Comunista-Combate (POC-Combate- Grupo de Paris), Debate (Comitê de Redação), Campanha, Outubro (pela reconstrução da IV Internacional no exterior), PCB, MR-8, Partido Comunista Brasileiro Revolucionário (PCBR) e um grupo denominado Juventude do MDB. O posicionamento das organizações variava da negação total à participação no pleito eleitoral à defesa da importância das eleições como elemento mobilizador das lutas contra o regime militar, passando por nuances táticas nas formas de atuação.

O POC-Combate defendia que a ditadura não seria derrubada através da via eleitoral criada pelo próprio regime, devendo o pleito ser denunciado como uma grande farsa. Em contrapartida, ponderava que a participação da organização deveria ser decidida através de uma avaliação de conjuntura, já que essa eleição poderia viabilizar a denúncia da farsa do processo eleitoral.

O grupo Debate partia do princípio que as eleições seriam uma tentativa dos militares de legitimarem o regime através do voto popular. Além disso, o próprio funcionamento do Legislativo significava uma grande ilusão, uma vez que as decisões eram tomadas à revelia de deputados e senadores. Ainda assim, para o agrupamento, as eleições deveriam ser usadas como forma de chamar a atenção para a verdadeira defesa da democracia, o que seria possível através do voto em candidatos do MDB que tivessem identificação clara com propostas populares e contra o regime. O programa mínimo a ser defendido era o da revogação do Ato Institucional n. 5 (Al-5), a instauração de uma Assembleia 
Constituinte com plenos poderes, voto universal, abolição dos órgãos de repressão, direito de organização sindical, etc. Nessa situação, ao defender o voto nulo, algumas organizações, em um momento de refluxo do movimento social, estariam deixando de aproveitar as eleições ("brechas do regime”) para denunciar o sistema ditatorial.

O posicionamento do grupo Campanha, por sua vez, indicava a não participação nas eleições. Para o jornal, o processo eleitoral seria de tal modo controlado pelos militares (utilizando-se da censura e dos meios repressivos) que não haveria condição de se fazer uma mínima propaganda democrática e popular contra o regime. Assim,

[...] tudo isso teria a consequência de que ao invés de significar uma acumulação de força ampliando nossa base, mostrando uma posição clara e independente, reforçando os setores mais avançados do proletariado e seus aliados, ao contrário disso, significaria uma perda importante de nossas poucas forças acumuladas, uma identificação (e confusão) frente às massas de nossos objetivos e métodos com os da "oposição" burguesa e a canalização do potencial de radicalização das massas para o reforço deste ou daquele setor da burguesia. (FRAÇÃO BOLCHEVIQUE, 1974, p. 8)

O grupo Outubro também era contrário à participação no pleito eleitoral. Para ele, defender o voto no MDB seria iludir os trabalhadores com a ideia de que o regime era representado apenas pela Arena e que seria possível acabar com a ditadura votando na "oposição". Nesse caminho, o grupo propõe a adoção de uma campanha pelo voto nulo, juntamente com a defesa de palavras de ordem democráticas e pela criação de uma Frente Única dos Trabalhadores (FRAÇÃO BOLCHEVIQUE, 1974, p. 9).

Muito próximo desse último posicionamento, estava o MR-8. Entendendo a farsa e a impossibilidade, naquelas condições, de uma eleição livre, defendia uma campanha de mobilização pelo voto nulo. Esse posicionamento não deveria, no entanto, significar passividade mas, sim, uma adesão intensa à campanha de denúncia do regime militar. O MR-8 esclarecia ainda que os militantes deveriam reafirmar sua posição ao anular o voto escrevendo nas cédulas palavras de ordem contra o regime, tais como "abaixo a ditadura", "pelo fim do arrocho 
salarial”, "abaixo a repressão e a tortura”, "eleição sem repressão", entre outras (FRAÇÃO BOLCHEVIQUE, 1974, p. 10).

O PCBR era mais uma entre as organizações contrárias à participação eleitoral. Argumentando que os movimentos de esquerda não tinham força suficiente para influir no processo político, sobretudo diante da repressão e do significado negativo do MDB, defendia que as energias da esquerda revolucionária fossem utilizadas para a organização dos trabalhadores. Uma campanha pelo voto nulo, ainda segundo o PCBR, só teria sentido caso houvesse um partido e um movimento de massas suficientemente fortes para fazer frente à máquina ditatorial (FRAÇÃO BOLCHEVIQUE, 1974, p. 11).

O PCB segue coerente com a proposta de Frente Única ampla, utilizandose de todas as brechas legais para a atuação que defendia desde meados dos anos 1960. Nesse sentido, aponta que, mesmo sendo uma farsa eleitoral, a participação das forças progressistas poderiam diminuir uma possível vitória dos setores ligados ao centro do poder ditatorial. Ao mesmo tempo, por menor que fossem os espaços, haveria a possibilidade de que candidatos progressistas usassem a campanha eleitoral para fazer denúncias contra o regime militar. Diante disso, considerava um grande erro a abstenção ou o voto nulo por parte das esquerdas (FRAÇÃO BOLCHEVIQUE, 1974, p. 11).

Por fim, a última contribuição vem da Juventude Democrática do MDB, a qual, evidentemente, defendeu a participação nas eleições. Para o grupo, seria um grande erro não aproveitar a possibilidade de debater e eleger candidatos progressistas. Lembra ainda que a abstenção e o voto nulo servem, ao final, à própria Arena, como teria ficado demonstrado com os dados da eleição de 1970: a Arena recebeu dez milhões e oitocentos mil votos; o MDB teve quatro milhões e setecentos mil votantes; e o total de brancos e nulos chegou ao número de treze milhões e trezentos mil. Assim, "se pode afirmar, à luz destes dados, que não votar no MDB foi uma efetiva ajuda à Arena e a propaganda desenvolvida pelo governo" (FRAÇÃO BOLCHEVIQUE, 1974, p. 11).

Como podemos perceber pelos posicionamentos acima mencionados, em 1974 a maior parte dos grupos remanescentes da esquerda revolucionária é contrária à participação eleitoral através do voto em candidatos do MDB. De 
forma geral, esses agrupamentos defendem a utilização do processo eleitoral para fazer denúncias do regime. A exceção é do grupo Debate, do qual trataremos adiante, que defende o voto em candidatos com clara identificação com as bandeiras dos trabalhadores e da democracia. Por fim, o PCB e a Juventude do MDB defendem a participação efetiva na campanha e no pleito eleitoral.

Ainda no Chile, havia outros jornais que, mesmo sem o objetivo específico de fazer o debate a respeito da luta armada, tratavam eventualmente do tema, como são os casos do Frente Brasileira de Informação (FBI) e, principalmente, do Brasil Hoy ${ }^{13}$, periódico ligado a militantes do PCB. No entanto, para os objetivos deste texto, utilizaremos dois periódicos que foram publicados na França, as revistas Debate e Brasil Socialista. Esses dois veículos destacam-se por terem iniciado a sua publicação antes da derrota do regime de Salvador Allende e por perpassarem toda a década de 1970, quando muitos dos militantes que se encontravam no Chile foram para Paris. Como já apontado, a experiência do golpe militar chileno foi mais um ingrediente para a autocrítica que continuaria na Europa.

A revista Debate: Problemas da Revolução Brasileira foi criada em fevereiro de 1970, durante o exílio na França, pelo ex-militante da Vanguarda Popular Revolucionária (VPR), João Quartim de Moraes, que havia deixado o Brasil após divergências no interior da VPR, conforme vimos anteriormente. A revista é uma das publicações mais relevantes da esquerda brasileira no exílio, entre outros motivos por sua longevidade. Criada em 1970, publicou 40 números e existiu até 1982, ano em que deixou de circular quando era publicada já no Brasil. Essa longa trajetória possibilitou ao grupo Debate vivenciar muitas das transformações pelas quais passou a esquerda brasileira no decorrer dos anos 1970: a crítica à luta armada, a problemática do eurocomunismo, o debate sobre a democracia, as

\footnotetext{
13 Por exemplo, em uma edição de 1972, afirmava que o balanço das ações armadas demonstrava que "quando afastadas das massas perdem seu sentido revolucionário e conduzem à destruição das organizações. Ensinam, ao mesmo tempo, que o caminho da luta política no Brasil passa pela organização das massas nos setores fundamentais da sociedade brasileira" (EL MODELO..., 1972, p. 7). No ano seguinte, o jornal publicava uma entrevista de Luís Carlos Prestes na qual ele afirmava que "os comunistas brasileiros estão convencidos de que o isolamento e a derrota da ditadura estão ligados ao crescimento da luta de massas e da unidade de ação das forças democráticas. Não se derrubará o regime atual lançando-se em aventuras desesperadas, sem o apoio das massas" (LA LUCHA..., 1973, p. 6).
} 
questões do movimento feminista, as greves de 1978, a fundação do PT, entre outras (ROLLEMBERG, 2007; PEZZONIA, 2011)

É importante ressaltar que, quando a revista Debate surgiu, ainda estavam em curso no Brasil as ações armadas de esquerda, por isso o periódico afirmava que seu objetivo era discutir a "política revolucionária no Brasil", não se tratando de uma posição favorável ou contrária à realidade da luta armada, mas sim da compreensão da "natureza política e militar da presente etapa da guerra revolucionária" (APRESENTAÇÃO, 1970, p. 1). Contudo, é possível observar que o posicionamento da revista em relação à luta armada era muito mais de crítica do que de apoio, o que se intensificou com o passar dos anos. Já no segundo número da revista, João Quartim de Moraes publicou o artigo "Introdução às teses de Debray", no qual defendia a atualidade das críticas que fizera ao militarismo no momento em que deixou a VPR (MORAES, 1970, p. 6-11). No mesmo número, foi publicado o artigo "Balanço da luta revolucionária no Brasil", assinado por Josué Costa, Saturnino da Silva e Alice Paiva. Os autores afirmam que as dificuldades e derrotas da luta armada não são resultado de erros operacionais, mas sim da própria linha política adotada (COSTA; SILVA; PAIVA, 1970, p. 17- 19).

Nas edições seguintes, e na medida em que a experiência guerrilheira era derrotada no Brasil, o posicionamento da revista em relação à luta armada fica mais explícito. Em 1971, a revista publicou o documento "Uma autocrítica necessária", da Tendência Leninista da ALN, importante questionamento ao militarismo, conforme visto anteriormente. Para o grupo Debate, o documento da TL era importante por afirmar

[...] a imperiosa necessidade de proceder a um exame crítico e autocrítico da experiência de luta revolucionária dos últimos anos, estimulando na prática este exame indispensável através de um documento dirigido não somente aos militantes da ALN, mas a "todos os marxistas leninistas", já que a todos eles cabe lutar pela "formação do partido marxista-revolucionário", os leninistas da ALN rompem corajosamente com o vanguardismo militarista não somente com suas manifestações mais aberrantes (por exemplo, na "teoria" de que na "primeira fase da revolução as massas serão mera massa de manobra de um punhado de guerrilheiros iluminados), mas também com suas formas mais sutis, e por isso mesmo mais perigosas politicamente, tais como 
elas se manifestam nas teses dos que revestem de uma linguagem "marxista" e "proletária" a tentativa de prosseguir nos erros da guerrilha urbana, que vêm se agravando cada vez mais na medida em que o radicalismo de classe média se tornou a ideologia dominante no seio da resistência armada. (APRESENTAÇÃO..., 1971, p. 30)

Uma boa síntese das análises e posicionamentos do grupo sobre a conjuntura política e atuação das esquerdas no Brasil pode ser vista nas repostas do Comitê de Redação às perguntas feitas pela Tendência Marxista Revolucionária da $4^{a}$ Internacional, e publicadas no periódico dessa organização, a revista Sous le Drapeau du Socialisme ${ }^{14}$. Questionado sobre a situação da esquerda revolucionária no país, o grupo apontava que esta tinha como característica principal o isolamento social. Afirmava ainda que os problemas das esquerdas estavam relacionados ao foquismo, que levou os grupos a menosprezarem a necessidade de uma organização nacional na forma de partido revolucionário (MOVIMIENTO..., 1972, p. 25-27).

Em 1973, a revista Debate publicou o seu programa, intitulado "Projeto de Plataforma Política”. Após a análise da conjuntura política e social, e das forças políticas em atuação, o grupo sintetiza em dois pontos seu projeto: o primeiro objetivo era contribuir para a ligação dos militantes de esquerda em geral e do movimento revolucionário em particular "à luta espontânea das grandes massas". A segunda meta era a reorganização de um Partido Comunista, "que constitua o destacamento mais avançado da classe operária e de todos os explorados e oprimidos e que assegure a hegemonia proletária na Revolução e a transformação socialista da Sociedade" (PROJETO..., 1973, p. 7).

Em meados dos anos 1970, quando crescia o movimento contra o regime militar com ênfase na bandeira democrática, a revista Debate definia como deveria se dar a presença dos comunistas na frente política contra a ditadura. 0 importante seria o pronunciamento de palavras de ordem amplas e comuns a todos os democratas que lutam pelas liberdades democráticas. Propostas “esquerdistas", como a criação de um "exército revolucionário", seriam estéreis, servindo apenas para isolar os revolucionários do movimento mais amplo da

\footnotetext{
${ }^{14}$ O material foi publicado também na revista Temas y Debates, na edição de março-abril de 1972, a qual utilizo aqui.
} 
sociedade. Um justo posicionamento por parte dos comunistas deveria contemplar uma perspectiva de massa e operária. Nesse caminho, Debate sintetiza os três requisitos às propostas dos comunistas:

1) ter um nítido caráter antiditatorial; 2) ser formulada de maneira a poder ser defendida em frente de massas diretamente expostas à repressão; 3) ter um conteúdo largamente democrático, mostrando que a grande linha de demarcação política em nosso país é a que passa entre o terror militar e a liberdade. (SITUAÇÃO..., 1976, p. 13)

A última revista publicada no exílio aqui analisada denomina-se Brasil Socialista. Criado na França, em 1975, o periódico veiculava em seus primeiros números as ideias de três organizações: a Ação Popular Marxista Leninista (APML), a Política Operária (PO) e o MR-8. Seu projeto, sintetizado no subtítulo "Organizar a resistência dos trabalhadores. Construir o Partido Revolucionário do Proletariado" 15 , era servir de base para a criação de uma "tendência proletária" na esquerda brasileira. A proposta central, portanto, estava voltada para o trabalho de base junto aos operários na luta contra a ditadura militar. Como perspectiva futura, figurava a criação de uma sociedade socialista. Porém, naquela conjuntura específica, e considerando a

[...] correlação de forças na sociedade e o baixo grau de consciência, mobilização e organização das forças revolucionárias, preocupa-nos especialmente em organizar, unir e fazer convergir contra o inimigo principal, a ditadura militar, todas as lutas operárias e populares, sejam elas de caráter econômico - contra a exploração dos trabalhadores, por melhores condições de vida e de trabalho - sejam elas de caráter político - pelas liberdades políticas para a classe operária e o povo, contra a opressão em todas as suas formas, contra o imperialismo [...]. Pois, os fatores decisivos para a derrubada da ditadura militar são a ação, a organização e a violência das massas trabalhadoras do país [...] (EDITORIAL, 1975, p. 2-3)

Ainda no primeiro número da revista, o MR-8 publicou o documento intitulado "Nossas tarefas no movimento operário", no qual detalhava o seu entendimento da forma de organização junto aos trabalhadores, sendo a fábrica o local privilegiado em que se deveria atuar. A ênfase estava no trabalho cotidiano, devendo os militantes buscar uma aproximação dos problemas e

\footnotetext{
${ }^{15}$ Sobre a criação da revista, ver Azevedo (2010).
} 
reivindicações sentidos pelo próprio operário, "por mais fragmentados, parciais ou reduzidos que estes fossem”. Para efetivação dessa tática política, propunha a criação de "comissões de empresa", formada por trabalhadores. No que diz respeito às bandeiras mobilizadoras, destacava aquelas voltadas à derrubada do arrocho salarial; estabilidade e direito ao trabalho; amparo à mulher, ao menor operário e ao trabalhador idoso e acidentado; melhores condições de trabalho; direito à saúde; direito à educação; direito à habitação; luta contra a carestia; liberdade de organização e manifestação; luta contra a ditadura militar. Clamavase, ainda,

[...] pela revogação do Al-5, pela revogação da lei de Segurança Nacional, pelo restabelecimento do habeas corpus. Contra as arbitrariedades policiais, perseguições políticas, torturas e assassinatos. Punição para todos os torturadores e responsáveis por assassinatos de presos políticos. (NOSSAS..., 1975, p. 27)

Em novembro de 1976, seriam realizadas eleições para vereadores e prefeitos na maior parte das cidades brasileiras, e a revista Brasil Socialista divulgou seu posicionamento em relação ao pleito eleitoral. Em primeiro lugar, criticava tanto os setores reformistas, por não deixarem claro que a eleição era uma farsa ditatorial, quanto os "doutrinaristas", que faziam campanha pelo voto nulo, entendendo ser essa a única forma de denúncia do regime militar. Para o grupo, ambas as posições estavam equivocadas e o papel dos revolucionários, sob uma bandeira proletária, era aproveitar a eleição para denunciar a ditadura e, ao mesmo tempo, eleger candidatos identificados com bandeiras democráticas e populares. Somente em locais em que não existissem políticos com esse perfil, o voto nulo deveria ser pregado (EDITORIAL, 1976, p. 1-5).

Como vimos, tendo surgido em 1975, a revista Brasil Socialista posicionouse, desde o início, a favor da participação nas eleições e das reivindicações pelas liberdades democráticas, considerando ser esse o caminho de organização das lutas contra o regime militar. Também desde o início defendeu o protagonismo dos trabalhadores e das massas nessa luta.

No decorrer de sua trajetória, muitos dos membros ligados à APML acabaram aderindo ao projeto de criação do Partido dos Trabalhadores, a partir das greves de 1978 e 1979. Essa opção se justificava pela ideia de que o PT 
representaria o projeto de um partido proletário independente e que, por isso, caberia aos revolucionários dele participar. Já o setor ligado ao MR-8 defendia que o partido enfraquecia a frente política contra a ditadura e, em consequência dessa análise, passou a atuar como corrente política no MDB, entendido como a legítima frente política (AZEVEDO, 2010).

Até o momento, tratamos basicamente da forma como as esquerdas revolucionárias, inicialmente no próprio país e, posteriormente, no exílio, debateram e fizeram a autocrítica da luta armada, buscando novas táticas e formas de atuação. No entanto, no decorrer da segunda metade dos anos 1970, enquanto esse debate ocorria no exterior, setores das esquerdas brasileiras, sob duras condições, continuavam, mesmo que de forma dispersa, presentes no país. E, nessa prática clandestina, as avaliações sobre a luta armada também apareciam como questão incontornável.

\section{A difícil derrota: o debate nas duras condições brasileiras}

No decorrer da segunda metade dos anos 1970, quando as organizações guerrilheiras haviam sido praticamente dizimadas pela repressão, parte dos militantes encontrava-se no exílio, enquanto outra parte continuava atuando no país, mesmo que de forma dispersa e sob forte risco de prisão. Foi nesse momento que, também internamente, intensificaram-se os debates sobre a autocrítica da luta armada e da experiência guerrilheira.

É o caso do PCdoB, que foi responsável pela guerrilha do Araguaia, ocorrida entre 1972 e 1974. O grupo era crítico das ações armadas urbanas empreendidas pela esquerda revolucionária de inspiração foquista e defendia uma proposta influenciada pelo exemplo revolucionário chinês, através do "cerco da cidade pelo campo" e da inserção dos militantes em meio aos camponeses. Depois de um processo de preparação, iniciado ainda na segunda metade dos anos 1960, o grupo acabou sendo responsável pelo maior enfrentamento armado contra os militares. Ao final, teve como saldo dezenas de mortos entre seus militantes e uma feroz repressão das forças armadas sobre a população da região do Araguaia $^{16}$.

\footnotetext{
${ }^{16}$ Sobre a história do PCdoB, ver Sales (2020).
} 
A derrota no Araguaia causou enorme debate no interior do PCdoB, divergências que acompanhariam o partido até os anos 1980. O que importa destacar aqui é que logo após o fim da guerrilha, ainda antes de o fato ter sido anunciado oficialmente para seus militantes, o PCdoB começou a dar os primeiros passos rumo a uma nova tática, ancorada na defesa da volta das liberdades políticas no país. O mês que marcou essa virada foi janeiro de 1975, quando o jornal A Classe Operária anunciou as resoluções tomadas pelo Comitê Central que acenavam para a defesa de uma política que entraria para a história partidária como as "três bandeiras": assembleia constituinte livremente eleita, abolição de todos os atos e leis de exceção e anistia geral (SALES, 2020).

De 1975 até o final da década, a política do PCdoB girou em torno da denúncia dos crimes praticados pela ditadura e da defesa das "três bandeiras". O principal caminho seguido foi a utilização dos espaços de oposição possíveis dentro do regime ditatorial, particularmente através da atuação no Movimento Democrático Brasileiro (MDB). Para o PCdoB, mesmo que fossem em grande parte uma farsa criada pelos militares, as eleições também podiam constituir-se em uma denúncia a partir das urnas. Dessa forma, o partido pregava o voto em massa no MDB, salvo naqueles locais em que não existissem candidatos do partido ou quando estes tivessem uma postura próxima dos candidatos da Aliança Renovadora Nacional (Arena). Nesse caso, o voto deveria ser nulo ou branco.

Outro tema que mobilizou o PCdoB na segunda metade da década de 1970 foi a luta pela anistia. Para o partido, o fortalecimento desse movimento poderia levar os militares à derrota. Para isso, a mobilização deveria atrair vários setores da sociedade, principalmente os populares, até a conquista plena da liberdade política e a derrota do regime discricionário. Naquele momento, a bandeira da anistia significava "a liberação imediata dos presos políticos e a anulação das condenações baseadas na Lei de Segurança; volta dos exilados e banidos e recuperação dos direitos políticos, sociais e profissionais dos militantes cassados pelos atos institucionais" (ANISTIA, 1978, p. 3).

O PCdoB realizava internamente, sob severas condições de isolamento e perigo, as avaliações sobre a derrota no Araguaia e as perspectivas de atuação 
política. O debate foi interrompido em dezembro de 1976, no episódio que ficou conhecido como Massacre da Lapa. Na ocasião, uma reunião do Comitê Central do partido foi interceptada pela polícia, que culminou no assassinato de três de seus dirigentes e na prisão e tortura de outros seis (SALES, 2020).

Com o fim da guerrilha do Araguaia, chegou ao fim a experiência da chamada luta armada contra a Ditadura Militar no Brasil. Como vimos, uma grande parte dos militantes foram exilados, porém outros permaneceram no país na segunda metade dos anos 1970. Em sua pesquisa sobre os novos movimentos sociais que surgiram no final dos anos 1970, Eder Sader (1988, p. 167-178) aponta a presença de inúmeros militantes oriundos de organizações clandestinas de esquerda em atuação nos movimentos urbanos e sindical.

Essa militância, ao se ver afastada das organizações, seja por causa do temor de ser presa, seja pela própria desarticulação da maior parte dos grupos de esquerda, juntou-se a grupos ligados à educação popular, ao sindicalismo e aos movimentos de bairro. Assim, para Sader, de certa forma, no Brasil o afastamento dos militantes do projeto da esquerda revolucionária se deu por uma questão pragmática: enquanto não retomava o contato com os partidos, os militantes atuavam nos movimentos de base da sociedade, nos quais inexistia espaço para as discussões ideológicas.

Muitos militantes, aos poucos, assumiram a identidade política de atuação junto aos movimentos sociais, deixando para trás as organizações de vanguarda. O autor cita casos de militantes do Partido Comunista Brasileiro Revolucionário (PCBR), da ALN e da Ala Vermelha, que acabaram optando pelos movimentos populares e de bairro (SADER, 1988, p. 174-175). Ainda de acordo com Sader (1988), esses militantes acabaram desempenhando papéis importantes junto aos movimentos sociais, não através de discussões sobre diretrizes estratégicas ou palavras de ordem, mas pelas explicações sobre o "funcionamento do capitalismo, da exploração da classe operária, das suas formas de luta" e das experiências de sua história. Um exemplo apontado pelo autor para essas temáticas elaboradas pelos militantes é um curso de formação, originalmente criado pela Polop, mas que depois foi reelaborado por outras organizações e, "em maior ou menor medida absorvidos pelas oposições sindicais, grupos de 
educação de base e mesmo nos treinamentos pastorais" (SADER, 1988, p. 177). As aulas básicas do curso sintetizavam as explicações marxistas sobre:

[...] as lutas de classe e os modos de produção como etapas do desenvolvimento histórico; a exploração capitalista, a partir da análise da mercadoria, da venda da força de trabalho e do conceito de mais-valia; o proletariado como a "classe revolucionária de nossos dias"; o Estado como instrumento de dominação; o socialismo e comunismo [...] (SADER, 1988, p. 177)

Há diversos outros exemplos da presença de militantes oriundos das organizações revolucionárias na segunda metade dos anos 1970 atuando no movimento sindical, de bairro e em outros espaços legais ${ }^{17}$, mas nem por isso com menor potencial de risco de prisão ${ }^{18}$. Entre as várias organizações que atuavam no país de forma clandestina no período, apontamos o caso da Ala Vermelha como exemplo dos novos caminhos trilhado por parte dos militantes da esquerda no período. A Ala, como vimos, foi uma das primeiras organizações a, ainda em 1969, iniciar o debate crítico sobre a luta armada. Com a derrota da experiência guerrilheira, em 1974 o grupo elaborou o documento chamado de Autocrítica, no qual rompia com a prática guerrilheira e apontava para a necessidade de inserção de seus militantes na base da sociedade.

Há pelo menos dois casos em que podemos identificar a presença dos militantes da Ala Vermelha nos movimentos surgidos na segunda metade dos anos 1970. No Rio de Janeiro, eles participaram de articulações no movimento sindical, particularmente entre os metalúrgicos ${ }^{19}$, e em movimentos de bairro na Baixada Fluminense, região metropolitana da cidade do Rio de Janeiro. Nos dois casos, de acordo com Ribeiro (2018), a ida dos militantes tanto para os sindicatos quanto para os bairros se deu a partir da decisão da direção da organização. Como resultado, o grupo participou de duas greves ocorridas em 1979 no estado

\footnotetext{
7 Registros da atuação de militantes de organizações comunistas no Brasil, na segunda metade dos anos 1970, podem ser vistos em Carone (1984) e Frederico (1987, 1990, 1991).

18 Vale lembrar que até o início dos anos 1980, setores de vigilância política estavam em plena atuação no país. Resende (2015) analisa a atuação do Deops-SP e do SNI sobre os movimentos pela Anistia até 1983. No ano seguinte, membros do PCB e do PCdoB ainda seriam presos acusados de atividades subversivas. Cf. http://memorialdademocracia.com.br/card/pf-fazcacada-final-aos-subversivos

${ }^{19}$ A Ala Vermelha foi uma das organizações que, entre 1969 e 1973, praticou a política de integração na produção, que consistia no envio de militantes para trabalharem em fábricas e, como isso, ampliar sua base social (RIBEIRO, 2013; 2018; NEGRO, 2009).
} 
do Rio, a greve da Fiat e a chamada "greve dos 300 mil". Já no movimento dos bairros, esteve presente particularmente em Nova Iguaçu, onde criou também um jornal chamado Jornal da Baixada (JOB): pobre, independente e atrevido, que utilizava uma linguagem acessível à população, característica de muitos jornais da chamada imprensa alternativa de caráter "basista" que surgiu no período.

Vale mencionar também a presença de militantes da Ala Vermelha na região do ABC paulista, junto ao movimento liderado pelos metalúrgicos de São Bernardo do Campo. Nesse caso, a inserção dos militantes se deu principalmente na área cultural, com a participação na criação do $A B C D$ Jornalº. Além disso, um ex-militante da Ala Vermelha, Renato Tapajós, desenvolveu uma série de atividades relacionadas ao setor audiovisual do Sindicado dos Metalúrgicos (RIBEIRO, 2018).

Um dado importante no processo de autocrítica da luta armada, mas pouco estudado até o momento, é o papel desempenhado por centenas de militantes que estiveram encarcerados no país. Entre vários outros casos, chama a atenção o exemplo do Presídio Tiradentes, em São Paulo, que recebeu dezenas de presos de várias organizações, sendo, por isso mesmo, constantemente citado nas memórias dos ex-militantes. Calcula-se que entre 1969 e 1973 tenham passado pelo presídio cerca de 300 presos políticos. A presença dos presos levava, naturalmente, às discussões sobre a situação do país e de suas organizações ${ }^{21}$.

Possivelmente, um dos primeiros temas discutidos era desvendar as circunstâncias das prisões, para tentar entender o funcionamento do aparelho repressivo, a infiltração de agentes policiais nas organizações, etc. Em seguida, com o reencontro de outros militantes da mesma organização, bem como as conversas entre membros de diferentes legendas, a discussão política ganhava força. Segundo Hamilton Pereira, ex-militante da ALN, foi no Presídio Tiradentes

\footnotetext{
20 A participação de ex-militantes da Ala Vermelha junto aos metalúrgicos do ABC, inclusive a experiência com cinema de Renato Tapajós, ver Ridenti (2000).

${ }^{21}$ Não são muitos os trabalhos que discutam o papel da prisão no processo de autocrítica dos militantes em relação à luta armada. Um livro relevante foi organizado por Alípio Freire, Izaías Almada e J. A. de Granville Ponce (1997). No Memorial da Resistência, na cidade de São Paulo, é possível encontrar diversos materiais, publicações e depoimentos de presos políticos do Presídio Tiradentes. Cf. https://acervo.fpabramo.org.br/ (Acesso: 28/05/2020). Para uma discussão mais recente, neste caso em uma prisão no estado do Ceará, ver Farias (2019).
} 
(e posteriormente nos presídios do Carandiru e do Barro Branco) que ele e um grupo de cerca de 12 militantes fizeram as primeiras avaliações sobre erros cometidos e a situação da organização. Nessa reflexão inicial, chegaram à conclusão, que "hoje parece óbvia, mas não era tanto assim na época”, de que a esquerda não entendeu o refluxo após o Al-5 e de que não havia solução política possível sem a presença das bases sociais (PEREIRA, 2019).

Um último exemplo representativo das reflexões construídas no período das prisões vem, mais uma vez, da Ala Vermelha. O documento ao qual nos referimos acima, denominado de Autocrítica, foi elaborado quando uma parte de seus dirigentes estava cumprindo pena no presídio Tiradentes. O texto foi escrito em partes e levado para fora do presídio pelas visitas recebidas pelos militantes. Um dos responsáveis pela escrita do documento foi Renato Tapajós, que viria a publicar, em 1977, o romance Em câmara lenta, o primeiro livro de literatura de testemunho sobre a experiência guerrilheira. De acordo com Ribeiro (2018), é possível encontrar no livro temáticas presentes no documento de autocrítica da Ala Vermelha.

Ao nos aproximamos do final da segunda metade dos anos 1970, é perceptível a mudança de postura dos grupos comunistas e dos militantes remanescentes, quando o afastamento da proposta de luta armada e a aproximação de diversos movimentos de base da sociedade consistiam aspectos centrais. De acordo com Maria Paula Nascimento Araújo, o debate das esquerdas nesse momento passa a ser polarizado em torno de três grandes temas: 1. A discussão sobre as propostas de reforma e/ou revolução (mas sem a perspectiva da luta armada); 2. A inserção na luta pelas liberdades democráticas; 3. Como conviver com os novos movimentos identitários e suas bandeiras específicas (ARAÚJO, 2000).

Em meio às diversas nuances e diferenças programáticas entre as organizações, acabaram prevalecendo, no decorrer da segunda metade da década de 1970, as propostas de inserção nos movimentos de base da sociedade e a adoção das bandeiras de resistência ao regime e das liberdades democráticas, o que, em certa medida, nas palavras de Araújo (2000, p. 124), significava uma "autocrítica, na prática, da experiência de luta armada [...]." 
Além dos debates programáticos e ideológicos realizados nos espaços restritos das esquerdas, mudanças nas concepções e atuação da maior parte delas podem ser compreendidas num breve panorama sobre alguns dos movimentos que emergiram ou se fortaleceram na segunda metade dos anos 1970. A começar pelo próprio MDB, que vai passar, cada vez mais, a ser visto como espaço de atuação política por parte de militantes e grupos revolucionários, recebendo, já na eleição de 1974, o apoio de alguns desses agrupamentos (ARAÚJO, 2007). Nas eleições seguintes, começariam a aparecer candidaturas, pelo MDB, de militantes de grupos de esquerda. Por exemplo, em 1976, MR-8 e APML lançaram a candidatura de Antonio Carlos Carvalho para vereador no Rio de Janeiro. Em 1978 era a vez de José Eudes, da APML sair como candidato a deputado estadual no Rio de Janeiro. Em 1982, Lúcia Arruda, da AP, e Liszt Vieira, ex-militante da VPR, foram eleitos vereadores na cidade do Rio (ARAÚJO, 2007). Também nas eleições de 1982, o PCdoB elegeu os deputados federais Aurélio Peres, por São Paulo; Haroldo Lima, pela Bahia; Aldo Arantes, por Goiás; e José Luiz Guedes, por Minas Gerais (SALES, 2020).

Por fim, como exemplo das mudanças ideológicas e táticas das esquerdas, basta lembrar a inserção de seus militantes em diversos movimentos coletivos no período. São os casos, além do movimento sindical e de bairro já citados, do Movimento Estudantil, sobretudo a partir de 1977; do Movimento Feminino pela Anistia, em 1975, e, principalmente, do Comitê Brasileiro pela Anistia (CBA), no final dessa década de 1970 (ARAÚJO, 2007). Todos esses movimentos acabaram tendo papel relevante na luta pela Anistia política no Brasil.

Em tempo, em verso e em movimento: a imprensa alternativa e as avaliações sobre a luta armada

Até o momento, analisamos como os diversos grupos e militantes de esquerda debateram e reformularam nos primeiros anos da década de 1970. Sob as condições de perseguição ditatorial, as discussões se davam em documentos clandestinos e eram restritas aos militantes. A partir de meados dessa década, no entanto, haverá uma ampliação dessa discussão, que passará a atingir um público mais amplo interessado em política e próximo das ideias de esquerda. 
Nesse caminho, um dos espaços privilegiados serão os jornais da chamada “imprensa alternativa” ou "nanica” (ARAÚJO, 2000).

Havia diversos jornais de imprensa alternativa em circulação no Brasil na segunda metade dos anos 1970. O foco dos periódicos era variado, incluindo desde os veículos envolvidos com questões culturais, àqueles ligados a movimentos de bairro, a sindicatos e os claramente comprometidos com a luta contra o regime militar. Para o escopo deste texto, importa destacar as discussões de três jornais que tinham como característica marcante a presença e influência de militantes e organizações de esquerda: Movimento, Em Tempo e versus ${ }^{22}$.

As avaliações e discussões feitas nesses jornais sobre a problemática da luta armada são parte constitutiva da memória social formada a respeito dessa experiência. Além disso, a presença de militantes que tinham participado ou apoiado, direta ou indiretamente, o projeto da esquerda revolucionária torna os periódicos da imprensa alternativa uma fonte importante para discutir e compreender o processo de autocrítica da experiência armada da esquerda brasileira.

O jornal Movimento foi criado em 1975, em plena vigência da censura, por jornalistas identificados com a crítica à ditadura militar. Por isso, inclusive, o periódico foi duramente perseguido pelos censores e teve várias de suas edições apreendidas. Além disso, como forma de intimidação, a polícia foi responsável pela explosão de bancas de jornal que o vendiam, como forma de fazer os jornaleiros boicotarem a sua circulação. Ainda assim, o Movimento tinha tiragem de cerca 20.000 exemplares e existiu até 1981, quando fechou por motivos financeiros e divergências internas.

Tendo circulado a maior parte do tempo sob rígida censura, foi só lentamente que as discussões sobre a experiência da luta armada (assunto prioritariamente proibido pela polícia) apareceram no jornal. Apenas na edição de julho de 1978, próximo, portanto, da abertura política, o Movimento trazia em sua

\footnotetext{
22 Sobre a imprensa alternativa, ver, entre outros: Kucinski (1991), Araújo (2000) e Aguiar (2012). Para uma visão geral da história do jornal Movimento, inclusive com a reprodução de algumas de suas matérias mais relevantes, ver Azevedo (2011).
} 
capa o destaque: "Finalmente revelada! História da guerrilha do Araguaia"23 (FINALMENTE..., 1978, p. 1). Nessa edição, há vários artigos sobre a guerrilha, como uma entrevista com o coronel Jarbas Passarinho, como representante do regime, e os depoimentos Elza Monnerat e José Genoino, participantes da guerrilha.

Em agosto, o jornal voltou a tratar do tema da guerrilha, desta vez urbana, ao apresentar uma matéria sobre a história de Frei Tito e o assassinato de Carlos Marighella. Em setembro, mais uma vez a questão do Araguaia volta à capa do periódico, que desta vez anuncia que a "A guerrilha chega à imprensa" (A GUERRILHA..., 1978, p. 1). O Movimento destacava, então, que, após matérias publicadas nele mesmo e em outros veículos da imprensa alternativa, a grande imprensa se interessou pelo assunto, que passou a aparecer em veículos como O Estado de S. Paulo, Jornal do Brasil, Folha de S. Paulo, Veja e IstoÉ. Salientase, assim, que a tônica do Movimento sobre a guerrilha do Araguaia é a defesa do direito de a sociedade brasileira conhecer sua história, até então censurada (OPERAÇÃO..., 1978, p. 9).

Aos poucos, com o recuo da censura e a volta dos exilados, podemos perceber uma maior variedade de publicações sobre a guerrilha brasileira. Em 1979, em uma reportagem sobre a morte de Marighella, o Movimento avalia que o regime queria deixar a história da guerrilha nos "porões dos arquivos policiais", argumentando que havia existido uma guerra na qual todos se envolveram, por isso seria melhor esquecer aqueles acontecimentos. Para o jornal, em contrapartida, se houve uma guerra, ela havia sido iniciada pelo regime militar. Afirma o periódico, por fim, que, se erraram os militantes, e na maior parte das vezes "pagaram caro pela ousadia", o mínimo de justiça que se espera para eles "é que suas lutas sejam corretamente avaliadas, e não simplesmente se percam na poeira dos arquivos" (CARVALHO, 1979, p. 13).

Em setembro de 1979, o jornal entrevistou alguns dos militantes anistiados que retornavam ao país, com perguntas relacionadas, entre outros temas, às avaliações sobre a luta armada. Para Ricardo Zaratini Filho, do PCBR, havia sido

\footnotetext{
${ }^{23}$ Antes disso, na edição 77, de 20 de dezembro de 1976, havia sido noticiada a operação policial que matou dirigentes do Partido Comunista do Brasil (PCdoB) que estavam em uma reunião no Comitê Central do partido na Lapa, São Paulo, episódio que ficou conhecido como "massacre da Lapa”. A matéria, porém, não trata propriamente da guerrilha, mas sim da operação policial.
} 
um erro a substituição das ações de massa pela "ação de pequenos grupos heroicos", perspectiva que estaria superada. Para ele, "agora, a luta é pela plena democratização e pela ampliação da frente democrática”. O militante do MR-8, Nelson Chaves dos Santos, também fez uma avaliação negativa do uso da luta armada nas condições políticas na década anterior. Defendeu ainda que o novo momento pedia uma atuação conjunta pela ampliação das lutas democráticas (FALAM..., 1979, p. 4).

Na mesma edição, foram publicadas matérias sobre a relação entre exmilitantes da luta armada, o PTB e o brizolismo. Segundo a correspondente do Movimento em Lisboa, os novos petebistas, oriundos da luta armada, explicam suas adesões ao trabalhismo a partir de dois argumentos. O primeiro seria "O fracasso no Brasil de todo tipo de política 'grupuscular', elitista, com um discurso clássico, afastado da realidade dos novos problemas do Brasil, sem capacidade de mobilizar as amplas massas". Em segundo lugar, "a consciência da grave crise dos modelos socialistas existentes no período e os impasses do movimento operário". Para eles, portanto, o PTB seria uma possibilidade de atuar em um grande partido popular (SALEM, 1979, p. 7).

Um dos ex-guerrilheiros que aderiram ao PTB foi Alfredo Sirkis, que fizera parte da VPR. Para ele, a luta armada fora a única forma possível de resistência naquela época (após 1968), uma vez que todas as outras portas estavam fechadas. Justamente por isso, a adesão à luta armada não foi uma opção estratégica, mas sim uma resposta a um momento da realidade brasileira. Para Sirkis, a nova situação do país apontava para a necessidade da luta legal e pacífica, buscando o aprofundamento do espaço democrático e da participação popular (SALEM, 1979, p. 7).

Em dezembro de 1979, o jornal lançou uma edição especial para discutir a luta armada, fazendo um balanço histórico pautado por uma afirmação colocada em sua capa: "Por que não deu certo". Entre outros materiais, o número é composto pela apresentação dos resultados de um debate organizado pelo jornal com o jornalista Fernando Portela e os militantes Apolônio de Carvalho, Hércules Corrêa, Mário Carvalho de Jesus, Franklin Martins e José Genoino. 
As respostas à primeira questão, que dizia respeito às causas da luta armada, apesar de certa variação, coincidiam na alegação do fechamento do regime e da necessidade de se fazer frente à violência institucionalizada. Nas palavras de Genoino, a luta armada consistiu numa tentativa direta de contraposição à violência do Estado e crítica "das causas que levaram à derrota o movimento de massas em 1964". Já para Franklin Martins, apesar de representar uma resposta a um regime "terrorista, sanguinário e selvagem", no nível "subjetivo", significou esquerdismo e voluntarismo por parte das esquerdas, que não levaram em consideração as reais condições de luta. Outra perspectiva que uniu os entrevistados foi a avaliação de que faltou base social para as esquerdas, que tentou, com ousadas ações, substituir as próprias massas (DEBATE, 1979, p. 5).

Ao final, as conclusões dos argumentos dos participantes deixam claros alguns pontos que marcam a autocrítica da esquerda brasileira em relação à luta armada. Apesar de "heroica", foi fruto de uma percepção equivocada das relações de poder e da força da ditadura militar. A partir dessa avaliação, a esquerda armada foi marcada pelo voluntarismo e pelo isolamento social. Nesse contexto, as avaliações passam a indicar caminhos de ação junto às massas populares e através de partidos amplos, seguindo tendência que já surgira nos debates ainda no exterior.

O jornal Em Tempo foi fundado em 1977 e dele faziam parte militantes e ex-militantes de várias organizações, como o MR-8, a APML e o MEP (Movimento pela Emancipação do Proletariado). Na sua fase final, foi dirigido pela corrente Democracia Socialista (DS), que estava dedicada ao projeto de criação do PT. Nesse periódico, chama a atenção a série de reportagens escritas por Marco Aurélio Garcia entre 1979 e 1980, nomeadas “Contribuição à história da esquerda brasileira". Nas mais de 30 edições da série, o autor percorreu diferentes aspectos da história das esquerdas no Brasil, focalizando os anos 1960 e 1970. Inicia com o impacto do golpe de 1964 no Partido Comunista Brasileiro (PCB) e o surgimento de uma nova esquerda, com grupos como a Ação Popular (AP), a Organização Revolucionária Marxista-Política Operária (ORM-POLOP) e o PCdoB. Em seguida, analisa diversas organizações da esquerda revolucionária e suas 
ações armadas contra a Ditadura Militar. Finaliza com uma apresentação da situação das esquerdas no período de distensão política, a partir de 1979.

Essa contribuição de Marco Aurélio Garcia (1979-1980) é, efetivamente, o primeiro esboço de uma história das esquerdas revolucionárias no Brasil. Mesmo que o autor não tivesse tal pretensão, e a publicação tenha se dado em um periódico, com espaço relativamente reduzido, estão lá presentes algumas das discussões que apareceriam em estudos posteriores sobre o tema. São os casos, por exemplo, da crise do PCB após o golpe de 1964, da influência da Revolução Cubana, do debate entre as chamadas linhas "massista" e "militarista" nas organizações, do distanciamento das esquerdas em relação à sociedade, entre outros assuntos relevantes.

Ainda que o autor assuma uma postura de isenção nas análises, de maneira geral, podemos afirmar que suas matérias são críticas à opção da esquerda brasileira pela luta armada nas condições políticas dos anos 1960. O ponto central da análise crítica está no isolamento social das esquerdas e da ausência de um partido político. Para Garcia, a esquerda brasileira optou pela luta armada quando o "castrismo" estava em grave crise, depois de derrotado na Venezuela, na Guatemala, no Peru e na Colômbia, além da derrota do próprio Che Guevara na Bolívia. A esquerda brasileira, portanto,

[...] ignorando as experiências históricas latino-americanas, mesmo as mais recentes, [...] se aprestava a repetir muitos dos erros cometidos por aqueles que, na sua ânsia de romper com teorias e práticas esclerosadas, haviam tentado "tomar os céus de assalto". A história se repetiria como tragédia. (GARCIA, 1979, p. 13)

Aos poucos o jornal Em Tempo assumiu um posicionamento em defesa da criação do PT, com muitas matérias destacando as greves do ABC e as movimentações pela criação partidária. De maneira geral, em suas páginas, a criação do PT aparecia como consequência da crise das esquerdas, da autocrítica da luta armada e da campanha pela redemocratização do país.

Por fim, o jornal Versus foi criado em 1975 e funcionou até 1979. O veículo tem uma trajetória peculiar entre aqueles que formavam a imprensa alternativa e eram críticos do regime militar. No início, consistia num jornal que destacava aspectos culturais, intelectuais e, de forma pioneira, oferecia grande espaço à 
cultura latino-americana. Contudo, a partir de 1977, passaram a fazer parte de sua administração e redação diversos militantes da Convergência Socialista (CS), o que modificou a proposta do jornal, que se tornou um veículo político.

O Versus fazia um balanço segundo o qual a experiência da luta armada teria sido rechaçada pela classe operária, o que ficava demonstrado pela facilidade com que foi vencida pelas forças governamentais. Diante disso, na conjuntura de meados dos anos 1970, impunha-se a necessidade da criação de um Partido Socialista e da participação no processo eleitoral que se aproximava (EDITORIAL, 1978, p. 3). A ênfase do programa socialista era a imersão nos movimentos sociais, deixando de lado qualquer perspectiva "ultraesquerdista" que tentasse substituir as ações de massa pelas de pequenos grupos (PROGRAMA..., 1978, p. 21).

A corrente Convergência Socialista, que nesse momento delineava a linha do jornal, propunha a criação de um partido socialista. Nos anos seguintes, porém, o grupo acabou enxergando no PT uma frente política na qual deveria agir, deixando de lado a proposta do partido socialista.

Conforme pudemos observar, a imprensa alternativa, através desses três jornais, demonstra como um setor da sociedade brasileira, a partir de uma perspectiva de esquerda, realizou a discussão sobre a luta armada dos grupos de esquerda nos anos 1960 e início dos anos 1970. Assim como a imprensa publicada no exílio, esses jornais apresentaram diversas críticas à experiência guerrilheira, particularmente no que diz respeito à questão do vanguardismo e do isolamento social dos grupos de esquerda. Como perspectiva política, aderiram às lutas pela redemocratização do país e muitos de seus membros acabaram optando por vários projetos políticos, como os representados pelo Partido do Movimento Democrático Brasileiro (PMDB), Partido Democrático Trabalhista (PDT), além dos diversos movimentos identitários que surgiram ou se fortaleceram na segunda metade dos anos 1970.

No entanto, em que pese a diversidade de caminhos seguidos pelos remanescentes da luta armada, a fundação do PT representou um capítulo fundamental na trajetória de grande parte desses homens e mulheres que haviam pegado em armas contra o regime militar. 
As esquerdas, a luta armada e O PT

O PT tem, predominantemente na sua origem, a presença de três tendências políticas e sociais: os metalúrgicos do ABC paulista, a esquerda católica e as chamadas correntes de esquerda. Entre estas, grande parte dos militantes de organizações que participaram da luta armada ingressou no movimento pela criação do PT. Entre outros, estão aqueles remanescentes da ALN, PCBR, APML, Ala Vermelha, Movimento pela Emancipação do Proletariado (MEP), Convergência Socialista, Democracia Socialista, Organização Socialista Internacionalista e $\mathrm{PRC}^{24}$. De acordo com Montenegro, na adesão dos vários grupos ao PT, ainda que em suas autocríticas fossem marcados por aspectos específicos,

[...] a rejeição à luta armada (ao menos de forma imediata) e a opção por buscar algum tipo de ação vinculada aos movimentos sociais e populares (em especial o sindical) era um elemento praticamente unânime entre os grupos e militantes remanescentes que se mostravam dispostos a seguir na luta pela transformação do país. (MONTENEGRO, 2011, p. 72)

No mesmo caminho, para Daniel Aarão Reis, o que unia todos esses grupos de esquerda, derrotados no enfrentamento radical da ditadura, era a atualização de uma antiga "utopia revolucionária”, que vinha pelo menos desde o Manifesto Comunista de 1848: a de que a emancipação dos trabalhadores deveria ser obra dos próprios trabalhadores:

[...] um partido independente do jogo e das instituições legais, livre da tutela do Estado e das lideranças burguesas, que sempre haviam dominado o jogo político nacional, distinto também das principais tradições que haviam animado as lutas sociais e políticas dos trabalhadores brasileiros: o trabalhismo e o comunismo, acusados de serem artífices de derrotas e, principalmente, de terem atrelado os trabalhadores a causas e a propósitos populistas e burgueses. (REIS, 2007, p. 507, grifos do autor)

\footnotetext{
${ }^{24}$ Há uma vasta produção sobre a história do PT, sobretudo pesquisas realizadas nos anos 1990. Para uma visão mais recente sobre a história do partido, ver Singer (2001), Reis (2007), Martinez (2007) e Secco (2011). Ver ainda um importante livro com entrevistas de militantes do partido que destaca a variedade de trajetórias que se juntaram na criação do PT. Cf. Ferreira; Fortes (2008).
} 
Muitos desses grupos, conforme tratei anteriormente, iniciaram a autocrítica da luta armada no momento em que se encontravam no exílio, enquanto outros militantes o fizeram internamente, nos movimentos sociais, na prisão e através da imprensa alternativa. Entre os temas do debate, estava a avaliação de que era necessária a criação de um partido político que rompesse com as características de vanguarda que marcaram os grupos de esquerda nos anos 1960 e 1970. Um segundo ponto relevante foi a crescente adesão às lutas contra o regime militar e pelas liberdades democráticas, também fruto da crítica ao vanguardismo e ao militarismo. A partir dessa análise, com a exceção principal do MR-8, no campo da luta armada, e do PCB e PCdoB, cada um deles se considerando o "verdadeiro" partido da classe operária, além daqueles que inicialmente preferiram permanecer no MDB, muitas das organizações de esquerda identificaram no PT a possibilidade de trabalho de base e de inserção social.

As avaliações de grupos e militantes que viam no PT a superação prática das ações vanguardistas que haveriam marcado as esquerdas nos anos 1970 podem ser encontradas em diversos documentos do período da fundação do PT, bem como em entrevistas e memórias de militantes construídas posteriormente. Em outubro de 1979, Marco Aurélio Garcia avaliava que a criação do PT representava a fusão, "em um só movimento", das amplas massas com aqueles [as esquerdas revolucionárias] que "certos ou errados - estiveram na primeira linha do confronto com a ditadura” (GARCIA, 1979 apud KAREPOVS, 2020, p. 410). Dessa forma, o partido "se anuncia como uma organização de massas capaz de resolver a crise de representação dos explorados e subverter todas as ideias herdadas sobre o que deve ser uma vanguarda de classe" (GARCIA, 1979 apud KAREPOVS, 2020, p. 410).

Em dezembro de 1979, Apolônio de Carvalho, que fez parte do PCBR, sendo também respeitado entre os militantes das diversas organizações de esquerda, apontava no PT o projeto para constituir um instrumento de vanguarda dos trabalhadores, "apoiado em formas de organização correspondente à nossa época”. Instrumento este que a esquerda revolucionária não conseguira 
desenvolver, na medida em que tentou "construir uma vanguarda política da classe operária à margem da classe operária" (GARCIA, 1979 apud KAREPOVS, 2020, p. 440).

Nesse sentido, para Alípio Freire, com a derrota das organizações armadas veio a derrota das concepções de luta armada. Esse processo se deu pelo esfacelamento de algumas organizações daquela época, como foi o caso da Ala Vermelha, ou por uma via de discussão interna. Por volta de 1973, para Freire, boa parte desses grupos e indivíduos deixa "de apostar numa luta armada imediata e passa a apostar num movimento de massas passando por caminhos diversos" (HARNECKER, 1994, p. 132).

De acordo com Paulo Vannuchi, ex-militante da ALN, as organizações guerrilheiras contribuíram na fundação do PT ao avaliarem que a derrota da luta armada não foi apenas uma mera questão estratégica, estando ligada a uma concepção política equivocada. Com a criação do PT, para Vannuchi, essa discussão estava superada, não sendo necessário fazê-la dentro do novo partido, pois o Partido dos Trabalhadores representava a "superação da esquerda anterior" (SECCO, 2011, p. 161). Hamilton Pereira, também ex-militante da ALN, entende que o PT significou o ponto de encontro entre a esquerda revolucionária, que havia sido dizimada pela ditadura, com o movimento operário e a proposta de criação de um partido reformista (PEREIRA, 2019). No mesmo sentido vão as avaliações de Bruno Maranhão, ex-militante do PCBR, para quem a orientação política da esquerda armada, apesar da disposição na luta contra o regime militar, mostrou-se equivocada (SECCO, 2011, p. 149).

Para alguns militantes oriundos da Ação Popular, o PT representava uma nova etapa na história das organizações de esquerda, que se exauriram sem conseguir criar um partido proletário (O PT..., 198-). Um último exemplo da inserção de ex-militantes da luta armada no PT é o de José Dirceu (2018), que fez parte do Movimento de Libertação Popular (Molipo). Dirceu, por volta de 1981, avaliava que a fundação do PT estava ligada à crise da esquerda brasileira, tanto aquela de vanguarda, quanto do próprio MDB: 
[...] frente a, por um lado, uma esquerda isolada do movimento social, dividida, dogmática ao elaborar propostas desligadas da realidade do país e, por outro lado, frente a partidos legais como - MDB, incapazes de superar seu caráter elitista, eleitoreiro e parlamentar, as lideranças e dirigentes surgidos da luta real dos trabalhadores e vários outros setores sociais travaram nos últimos anos contra a política econômica no regime, aprenderam, na prática, a necessidade de um partido político legal, de massa e de luta, democrático, que organizasse os trabalhadores brasileiros. (DIRCEU, 1981, p. 7)

A presença de representantes dos vários grupos de esquerda no interior do PT levou a intenso debate nesse partido sobre a sua própria identidade como agremiação. Ao passo que muitos dirigentes, particularmente os operários do ABC, queriam um partido coeso em torno de propostas unitárias, vários outros, sobretudo as organizações políticas que ainda mantinham estrutura própria, viam no PT um espaço de frente política ou como embrião de um partido de vanguarda. Nesse caminho, o Partido dos Trabalhadores seria um meio para a realização de uma das propostas principais da esquerda revolucionária desde meados dos anos 1970, que consistia na criação de um partido socialista.

Essas divergências levaram a uma grande discussão a respeito do que se convencionou chamar de "questão das tendências internas". Entre outros pontos, questionava-se a possibilidade de os grupos presentes no PT manterem estruturas organizacionais paralelas às do partido, bem como a obrigação dos militantes de acatarem as decisões tomadas nos congressos do partido. Ao final do debate, prevaleceu a ideia de que haveria liberdade de intervenção interna, mas sem uma estrutura paralela por parte das organizações de esquerda. Ao mesmo tempo, os próprios grupos de esquerda, seja a partir de decisões políticas, seja a partir do próprio ingresso individual de seus militantes, acabaram se incorporando ao projeto do $\mathrm{PT}^{25}$.

Para muitos militantes e organizações da esquerda revolucionária, em meados dos anos 1980, com a consolidação do PT e de outros novos partidos e movimentos populares, chegava ao fim o processo de autocrítica da luta armada

\footnotetext{
${ }^{25}$ Sobre o debate a respeito das tendências, ver: Dirceu e Pomar, 198-; Arbix e Cunha, 1986; Boletim..., 1992. Ver ainda uma coletânea de documentos sobre as tendências do PT, in: Alves, 2018.
} 
iniciada cerca de 10 anos antes. A trajetória dessa transformação da esquerda, portanto, pode ser acompanhada historicamente por meio de seus debates, documentos e entrevistas. Dos primeiros anos da autocrítica, passando pelo intenso debate no exílio, as discussões sobre o processo de redemocratização, a participação no MDB, a relação com o movimento pela criação do PT, bem como a forma de inserção nesse novo partido e em novos movimentos, completam o percurso de uma parte da esquerda revolucionária brasileira.

Abria-se, a partir desse momento, outra fase na história da esquerda brasileira, marcada, entre outros temas, pela crise do socialismo real e a inserção na política institucional. Nesse caminho, as ideias de revolução e socialismo ficaram cada vez mais distantes da maior parte da esquerda brasileira, resistindo ainda em pequenos grupos de pouca expressão social.

O debate, iniciado em 1979, a partir da publicação do texto de Carlos Nelson Coutinho intitulado "Democracia como valor universal", e aprofundado no decorrer da primeira metade dos anos 1980, pode exemplificar a aceitação pela maior parte esquerda brasileira da proposta segundo a qual as bandeiras de defesa da democracia e de construção de um socialismo igualmente democrático estariam consolidadas em seu projeto político na conjuntura que se abria com o fim do regime militar (COUTINHO, 1979) ${ }^{26}$.

\section{Conclusões}

Este artigo procurou indicar algumas respostas para as questões da problemática do percurso da autocrítica da esquerda brasileira em relação à experiência da luta armada. As conclusões às quais cheguei foram as de que os debates, as avaliações e as autocríticas das esquerdas brasileiras se deram lentamente entre o início dos anos 1970, momento que marca o fim das ações guerrilheiras no país, e meados dos anos 1980, quando se consolida o projeto de criação do Partido dos Trabalhadores e outras perspectivas políticas, em geral

\footnotetext{
${ }^{26}$ Sobre o debate a respeito da democracia, ver, entre outros: Coutinho (1979) e Weffort (1984). Ver ainda a publicação do seminário intitulado “As esquerdas e a democracia”, realizado em 1986, e do qual participaram diversos intelectuais que estavam diretamente envolvidos nessa discussão. Cf. Garcia (1986).
} 
buscando-se uma inserção na base da sociedade, sobretudo entre os trabalhadores urbanos e rurais.

Nesse sentido, a inserção dos militantes da luta armada no processo de democratização, no começo dos anos 1980, resultou de uma reflexão iniciada em meados da década anterior. Essa adesão a novos projetos políticos surgidos após o declínio da luta armada é plenamente inteligível a partir de uma pesquisa baseada nos debates e documentos produzidos pelos próprios militantes e grupos de esquerda no decorrer dos anos 1970. Em outras palavras, a mudança na atuação dos militantes resulta de um debate histórico, na medida em que se insere na conjuntura de fim do regime militar; e também político-ideológico, já que se trata da modificação dos seus projetos de transformação social.

Nesse caminho, não me parece que essas mudanças possam ser entendidas apenas tendo como chave analítica as metamorfoses ou deslocamentos de memória realizados após a adoção das bandeiras democráticas por parte desses militantes, conforme defendem alguns autores ${ }^{27}$. A transformação dos projetos revolucionários dos anos 1960 para bandeiras democráticas e de inserção social no início dos anos 1980, parece-me resultar desse longo processo político, vivenciado entre o final da ditadura militar e a consolidação da democracia no país. Processo durante o qual no Brasil, bem como em outras partes do mundo ocidental, a ideia de revolução cedeu lugar à preponderância da ideia de democracia política, sem que isso, contudo, tenha significado a construção de uma verdadeira democracia social.

\footnotetext{
${ }^{27}$ Para a perspectiva segundo a qual teria havido uma metamorfose dos militantes da luta armada em defensores da democracia a partir de uma operação de memória em meio ao processo de redemocratização, ver Reis (2000), Rollemberg (2003) e Angelo (2011).
} 


\section{Referências}

ALA VERMELHA. Os 16 pontos. Doc. 21. APERJ, FDARF, DDI-I, nov. 1969.

ALA VERMELHA. Autocrítica (1967-1973). Doc. 18. Fundo DARF, AV, DDI-II, 1974.

ALGUNS problemas da luta armada no Brasil. Temas y Debates, Santiago, p. 34, n. 1, set. 1970.

ALN, MR-8. Resistência. Ano III, n. 1, nov. 1972. Edição para o Chile.

ANISTIA ampla, irrestrita, às vítimas da ditadura. A Classe Operária, São Paulo, p. 3, abr. 1978.

APRESENTAÇÃO. Debate, Paris, p. 1, n. 1, fev. 1970.

APRESENTAÇÃO do documento pela Redação de Debate. Debate, Paris, p. 1-7, n. 7, set. 1971.

ARAÚJO, Maria Paula Nascimento. Lutas democráticas contra a ditadura. In: FERREIRA, Jorge; REIS, Daniel Aarão (org.). Revolução e democracia (1964...). Rio de Janeiro: Civilização Brasileira, 2007. p. 321-353.

AZEVEDO, Carlos. Jornal Movimento: uma reportagem. Belo Horizonte: Editora Manifesto, 2011.

AZEVEDO, Ricardo. Por um triz: memórias de um militante da AP. São Paulo: Plena, 2010.

A GUERRILHA chega à imprensa. Movimento, São Paulo, p. 11, n. 168, 18 set. 1978.

CARVALHO, Flávio de. Há dez anos: cerco e aniquilação do terror. Movimento, São Paulo, p. 11-13, n. 216, 26 ago. 1979.

CHAGAS, Fábio André Gonçalves das. A vanguarda popular revolucionária: dilemas e perspectivas da luta armada no Brasil (1968-1971). 2000. Dissertação (Mestrado em História) - Departamento de História, Unesp, Franca, 2000.

CHIRIO, Maud. Les trajectoires intellectuelles et politiques des exilés brésiliens pendant le regime militaire (1964-1979). Diplôme d'études approfondies (DEA), Paris, Université Paris, 2004.

COSTA, Josué; SILVA, Saturnino da; PAIVA, Alice. Balanço da luta revolucionária no Brasil. Debate, Paris, p. 17-21, n. 2, abr. 1970. 
COUTINHO, Carlos Nelson. A democracia como valor universal. Encontros com a civilização brasileira. Rio de Janeiro: [s.n.], mar. 1979. n. 9. p. 33-48.

DEBATE. Movimento, São Paulo, p. 1-15, n. 235, 31 dez. 1979.

DIRCEU, José. O PT nasce da crise da esquerda. Em Tempo, p. 4, São Paulo, 18 fev. 1981.

DIRCEU, José. Zé Dirceu: memórias. São Paulo: Geração Editorial, 2018.

EDITORIAL. Temas y Debates, Santiago, p. 5, n. 10, jan./fev. 1973.

EDITORIAL. Brasil Socialista, Paris, ano I, p. 1-3, n. 1, jan. 1975.

EDITORIAL. Brasil Socialista, Paris, ano II, p. 1-2, n. 7, out. 1976.

EDITORIAL. Versus, São Paulo, p. 1, n. 21, maio/jun. 1978.

EL MODELO brasileño. Brasil Hoy, Santiago, p. 3, n. 1, set./out. 1972.

FALAM os anistiados. Movimento, São Paulo, p. 7-8, n. 218, 9 set. 1979.

FICO, Carlos. Ditadura militar brasileira: aproximações teóricas e historiográficas.

Revista Tempo e Argumento, Florianópolis, v. 9, n. 20, p. 05-74, jan./abr. 2017.

FINALMENTE revelada! História da guerrilha do Araguaia. MOVIMENTO. São Paulo, n. 159, p. 1, 17 de julho de 1978.

FRAÇÃO BOLCHEVIQUE. Hacer del Exilio una Campaña. Campanha, Santiago, p. 1, n. 1,28 set. 1972.

FRAÇÃO BOLCHEVIQUE. Construir el partido obrero. Campanha, Santiago, n. 1, 28 set. 1972 a.

FRAÇÃO BOLCHEVIQUE. Debate. Campanha, Paris, n. 20, 5 nov. 1974.

FREIRE, Américo. A via partidária na transição política brasileira. In: QUADRAT, Samantha Viz (org.). Não foi tempo perdido: os anos 80 em debate. Rio de Janeiro: 7 letras, 2014. p. 9-33.

GARCIA, Marco Aurélio. Como surge a esquerda armada brasileira. Em Tempo, São Paulo, 19 set. 1979. 
HARNECKER, Marta. O sonho era possível: a história do Partido dos

Trabalhadores narrada por seus protagonistas. São Paulo: MPLA, 1994.

KAREPOVS, Dainis (org.). Notas para uma história dos trabalhadores: contribuição à história da esquerda brasileira e outros escritos (textos selecionados de Marco Aurélio Garcia). São Paulo: IMAG; Fundação Perseu Abramo, 2019.

LA LUCHA revolucionaria de los comunistas brasileños. Brasil Hoy. Santiago, n. 2, jan./fev. 1973.

MONTENEGRO, Darlan. A esquerda brasileira contra a política: organizações guerrilheiras e renúncia à estratégia no período da luta armada. Revista Estudos Políticos, Niterói, n. 2, p. 64-80, 2011.

MORAES, João Quartim de. Introdução às teses de Debray. Debate, Paris, n. 2, abr. 1970.

MOVIMIENTO revolucionario en Brasil. Temas y Debates, Santiago, n. 6, mar./abr. 1972.

NAPOLITANO, Marcos. Recordar é viver: as dinâmicas e vicissitudes da construção da memória sobre o regime militar brasileiro. Antíteses, Londrina, v. 8, n. 15, p. 9-44, nov. 2015. Edição especial.

NEGRO, Antonio Luigi. Servir ao povo de todo o coração: mulheres militantes e mulheres operárias no ABC na década de 1970. In: SANTOS, Cecília Macdowell; TELES, Edson; TELES, Janaína de Almeida (org.). Desarquivando a ditadura: memória e justiça no Brasil. São Paulo: Aderaldo \& Rothschild Editores, 2009. v. 1. p.84-109.

NOSSAS tarefas no movimento operário. Brasil Socialista, Paris, ano I, n. 1, jan. 1975.

OPERAÇÃO batina branca. Movimento, São Paulo, n. 162, 7 ago. 1978.

O PT e vanguarda. Fundo Ação Popular, São Paulo: Fundação Perseu Abramo, 198-.

PEREIRA, Hamilton. Entrevista. [Entrevista cedida a] Jean Sales e Alexandre Fortes. História Oral: PT 40 anos, São Paulo, set. 2019. Disponível em: https://fpabramo.org.br/csbh/memoria-de-militancia/. Acesso em: 28 maio 2020. 
PEZZONIA, Rodrigo. Revolução em DEBATE: o grupo DEBATE, o exílio e a luta armada no Brasil (1970-1974). 2011. Dissertação (Mestrado em Sociologia) Departamento de Sociologia, Unicamp, Campinas, 2011.

POLLAK, Michael. Memória, esquecimento e silencio. Estudos Históricos, Rio de Janeiro, v. 2, n. 3, p. 3-15, 1989.

POLLAK, Michael. Memória e identidade social. Estudos Históricos, Rio de Janeiro, v. 5, n. 10, p. 200-212, 1992.

PROGRAMA para o PS. Versus, São Paulo, n. 25, out., 1978.

PROJETO de Plataforma Política. Debate, Paris, n. 12, abr. de 1973.

REIS, Daniel Aarão. Ditadura e democracia no Brasil. Rio de Janeiro: Zahar, 2014.

REIS, Daniel Aarão. O Partido dos Trabalhadores: trajetória, metamorfoses, perspectivas. In: FERREIRA, Jorge; REIS, Daniel Aarão (org.). Revolução e democracia (1964...). Rio de Janeiro: Civilização Brasileira, 2007. p. 503-540.

REIS, Daniel Aarão et al. Versões e ficções: o sequestro da história. São Paulo: Fundação Perseu Abramo, 1997.

REIS, Daniel Aarão; RIDENTI, Marcelo; MOTTA, Rodrigo Patto Sá (org.). O golpe e a ditadura militar 40 anos depois (1964-2004). Bauru: Edusc, 2004.

RESENDE, Pâmela de Almeida. Os vigilantes da ordem: a cooperação Deops-SP e SNI e a suspeição aos movimentos pela Anistia (1975-1983). Rio de Janeiro: Arquivo Nacional, 2015.

RIBEIRO, Adriana Maria. Todo comunista tem de ir aonde o povo está: as experiências de inserção política da Ala Vermelha na Baixada Fluminense na década de 1970. 2013. Dissertação (Mestrado em História) - Departamento de História, UFRRJ, Seropédica, 2013.

RIBEIRO, Adriana Maria. Em nome da revolução: a trajetória social e política da Ala Vermelha (1967-1985). 2018. Tese (Doutorado em História) - Departamento de História, UFRRJ, Seropédica, 2018.

RIDENTI, Marcelo. Resistência e mistificação da resistência armada contra a ditadura: armadilhas para pesquisadores. In: RIDENTI, Marcelo; MOTTA, Rodrigo. Patto Sá (org.). O golpe e a ditadura militar 40 anos depois (1964-2004). Bauru: Edusc, 2004. p. 53-65. 
ROLLEMBERG, Denise. Debate no exílio em busca da revolução. In: RIDENTI, Marcelo; REIS, Daniel Aarão (org.) História do marxismo no Brasil: partidos e movimentos após os anos 1960. Campinas: Editora da Unicamp, 2007. p. 291339.

ROLLEMBERG, Denise. Esquecimento das memórias. In: MARTINS FILHO, João Roberto (org.). O Golpe de 1964 e o Regime Militar: novas perspectivas. São Carlos: EdUFSCar, 2006. p. 81-91.

ROLLEMBERG, Denise. O apoio de Cuba à luta armada no Brasil: o treinamento guerrilheiro. Rio de Janeiro: Mauad, 2001.

SADER, Eder. Quando novos personagens entraram em cena: experiências e lutas dos trabalhadores da grande São Paulo - 1970-1980. Rio de Janeiro: Paz e Terra, 1988.

SALES, Jean Rodrigues. Entre a revolução e a institucionalização: uma história do Partido Comunista do Brasil (PCdoB). São Paulo: Edusp, 2020.

SALEM, Helena. Os guerrilheiros de Brizola. Movimento, São Paulo, n. 218, set. 1979.

SECCO, Lincoln. História do PT. São Paulo: Ateliê Editorial, 2011.

SILVA, Helenice Rodrigues da. "Rememoração"/comemoração: as utilizações sociais da memória, São Paulo. Revista Brasileira de História [online], [S.L.], v. 22, n. 44, p. 425-438, 2002.

SILVA, Tadeu Antonio Dix. Ala Vermelha: revolução, autocrítica e repressão judicial no Estado de São Paulo (1967-1974). 2007. Tese (Doutorado em História) - Departamento de História, USP, São Paulo, 2007.

SITUAÇÃO política nacional e a luta pela democracia. Debate, Paris, n. 21, fev. 1976.

TL (Tendência Leninista). Uma autocrítica necessária. Temas y Debates, Santiago, n. 6, 1975. Suplemento.

TL (Tendência Leninista). Unidade e Luta, Santiago, n. 1, maio/jun. 1972a.

TL (Tendência Leninista). Unidade e Luta, Santiago, n. 5 e 6, jan./abr. 1973. 


\section{Leitura complementar}

AGUIAR, Flávio. Imprensa alternativa: opinião, movimento e em tempo. In: MARTINS, Ana Luiza; DE LUCCA, Tânia Regina (org.). História da imprensa no Brasil. São Paulo: Contexto, 2012, p. 233-248.

ALVES, Sarkis (org.). As tendências internas do Partido dos Trabalhadores: pluralidade e democracia. Perseu: história, memória e política. São Paulo: Fundação Perseu Abramo, 2018. p. 101-199.

ANGELO, Vitor Amorim de. Ditadura militar, esquerda armada e memória social no Brasil. 2011. Tese (Doutorado em Ciência Política) - Departamento de Ciências Sociais, UFSCAR, São Carlos, 2011.

ARAÚJO, Maria Paula Nascimento. A utopia fragmentada: as novas esquerdas no Brasil e no mundo na década de 1970. Rio de Janeiro: FGV, 2000.

ARBIX, Glauco; CUNHA, Raimundo. A respeito de uma discussão sobre tendências no PT (resposta ao texto de José Dirceu e Wladimir Pomar). São Paulo: Fundação Perseu Abramo, abr. 1986.

BOLETIM Interno da Tendência Democracia Socialista, n. 6. São Paulo: Fundação Perseu Abramo, maio 1992.

CRUZ, Fábio Lucas da. Brasileiros no exílio: Argel como local estratégico para a militância política (1965-1979). 2016. Tese (Doutorado em História) - USP, São Paulo, 2016.

CRUZ, Fábio Lucas da. Frente brasileño de informaciones e campanha: os jornais de brasileiros exilados no Chile e na França (1968-1979). 2010.

Dissertação (Mestrado em História) - Departamento de História, USP, São Paulo, 2010.

DIRCEU, José; POMAR, Wladimir. Algumas considerações sobre as tendências organizadas no PT. São Paulo: Fundação Perseu Abramo, 198-.

FARIAS, Airton de. Pavilhão sete: presos políticos da ditadura civil-militar. Fortaleza: Expressão Gráfica Editora, 2019.

FERREIRA, Marieta de Moraes; FORTES, Alexandre (org.). Muitos caminhos, uma estrela: memórias de militantes do PT. São Paulo: Editora Fundação Perseu Abramo, 2008.

FREDERICO, Celso. A esquerda e o movimento operário: 1964-1984. Belo Horizonte: Oficina de Livros, 1990. v. 2. 
FREDERICO, Celso. A esquerda e o movimento operário: 1964-1984. Belo Horizonte: Oficina de Livros, 1991. v. 3.

FREDERICO, Celso. A esquerda e o movimento operário: 1964-1984. São Paulo: Editora Novos Rumos, 1987. v. 1.

FREIRE, Alípio; ALMADA, Izaías; PONCE, J. A. de Granville (org.). Tiradentes: um presídio da ditadura. São Paulo: Scipione, 1997.

GARCIA, Marco Aurélio. As esquerdas e a democracia. Rio de janeiro: Paz e Terra, 1986.

GORENDER, Jacob. Combate nas trevas. São Paulo: Ática, 1987.

KUCINSKI, Bernardo. Jornalistas e revolucionários: nos tempos da imprensa alternativa. São Paulo: Scritta, 1991.

MARQUES, Teresa Cristina Schneider. Militância política e solidariedade transnacionais: a trajetória política dos exilados brasileiros no Chile e na França (1968-1919). 2011. Tese (Doutorado em Ciência Política) - Departamento de Ciências Sociais, UFRGS, Porto Alegre, 2011.

MARTINEZ, Paulo Henrique. O Partido dos Trabalhadores e a conquista do Estado. 1980-2005. In: RIDENTI, Marcelo; REIS, Daniel Aarão (orgs.). História do marxismo no Brasil: partidos e movimentos após os anos 1960. Campinas: Editora da Unicamp, 2007. p. 239-288.

NAPOLITANO, Marcos. No exílio, contra o isolamento: intelectuais comunistas, frentismo e questão democrática nos anos 1970. Estudos Avançados, São Paulo, v. 28, n. 80, p. 41-58, jan/abr. 2014.

REIS, Daniel Aarão. A revolução faltou ao encontro: os comunistas no Brasil. 2. ed. São Paulo: Brasiliense, 1990.

REIS, Daniel Aarão. Ditadura militar, esquerdas e sociedade. Rio de Janeiro: Zahar, 2000.

RIDENTI, Marcelo. Em busca do povo brasileiro: artistas da revolução, do CPC à era da tv. Rio de Janeiro: Record, 2000.

RIDENTI, Marcelo. O fantasma da revolução brasileira. São Paulo: Editora da Unesp, 1993. 
ROLLEMBERG, Denise. Esquerdas revolucionárias e luta armada. In: FERREIRA, Jorge; DELGADO, Lucila Neves de Almeida (org.). O Brasil republicano: o tempo da ditadura. Rio de Janeiro: Civilização Brasileira, 2003. p. 43-91.

ROLLEMBERG, Denise. Exílio: entre raízes e radares. Rio de Janeiro: Record, 1999.

SALES, Jean Rodrigues (org.). Guerrilha e revolução: a luta armada contra a ditadura militar no Brasil. Rio de Janeiro: Lamparina, $2015 a$.

SALES, Jean Rodrigues. A luta armada contra a ditadura militar: a esquerda brasileira e a influência da Revolução Cubana. São Paulo: Perseu Abramo, 2007.

SALES, Jean Rodrigues. Guerrilha e revolução: um balanço dos estudos e debates sobre a luta armada contra a ditadura militar no Brasil. In:

ZACHARIADHES, Grimaldo Carneiro (org.). 1964: 50 anos depois - a ditadura em debate. Aracaju: EDISE, 2015b. p. 171-216.

SINGER, André. O PT. São Paulo: Publifolha, 2001.

TL (Tendência Leninista). Comunicado de la Tendencia Leninista da ALN. Temas y Debates, Santiago, n. 6, mar./abr. 1972.

WEFFORT, Francisco Correia. Por que democracia? São Paulo: Brasiliense, 1984. 